\title{
The (pro)renin receptor (ATP6ap2) facilitates receptor-mediated endocytosis and lysosomal function in the renal proximal tubule
}

\author{
Marta Figueiredo ${ }^{1} \cdot$ Arezoo Daryadel $^{1} \cdot$ Gabin Sihn $^{2} \cdot$ Dominik N. Müller $^{2,3,4} \cdot$ Elena Popova $^{2} \cdot$ Anthony Rouselle $^{2}$. \\ Genevieve Nguyen $^{5} \cdot$ Michael Bader $^{2,4,6,7} \cdot$ Carsten A. Wagner ${ }^{1}$
}

Received: 8 February 2021 / Revised: 26 May 2021 / Accepted: 16 June 2021 / Published online: 6 July 2021

(c) The Author(s) 2021

\begin{abstract}
The ATP6ap2 (Pro)renin receptor protein associates with $\mathrm{H}^{+}$-ATPases which regulate organellar, cellular, and systemic acid-base homeostasis. In the kidney, ATP6ap2 colocalizes with $\mathrm{H}^{+}$-ATPases in various cell types including the cells of the proximal tubule. There, $\mathrm{H}^{+}$-ATPases are involved in receptor-mediated endocytosis of low molecular weight proteins via the megalin/cubilin receptors. To study ATP6ap2 function in the proximal tubule, we used an inducible shRNA Atp6ap2 knockdown rat model (Kd) and an inducible kidney-specific Atp6ap2 knockout mouse model. Both animal lines showed higher proteinuria with elevated albumin, vitamin D binding protein, and procathepsin B in urine. Endocytosis of an injected fluid-phase marker (FITC- dextran, $10 \mathrm{kDa}$ ) was normal whereas processing of recombinant transferrin, a marker for receptormediated endocytosis, to lysosomes was delayed. While megalin and cubilin expression was unchanged, abundance of several subunits of the $\mathrm{H}^{+}$-ATPase involved in receptor-mediated endocytosis was reduced. Lysosomal integrity and $\mathrm{H}^{+}$-ATPase function are associated with mTOR signaling. In ATP6ap2, KO mice mTOR and phospho-mTOR appeared normal but increased abundance of the LC3-B subunit of the autophagosome was observed suggesting a more generalized impairment of lysosomal function in the absence of ATP6ap2. Hence, our data suggests a role for ATP6ap2 for proximal tubule function in the kidney with a defect in receptor-mediated endocytosis in mice and rats.
\end{abstract}

Keywords Proximal tubule $\cdot$ Low molecular weight proteins $\cdot$ Lysosome $\cdot \mathrm{H}^{+}$-ATPase $\cdot$ Endocytosis

Marta Figueiredo and Arezoo Daryadel share first authorship.

Michael Bader

mbader@mdc-berlin.de

$\bowtie$ Carsten A. Wagner

Wagnerca@access.uzh.ch

1 Institute of Physiology, University of Zurich, Winterthurerstrasse 190, CH-8057 Zurich, Switzerland

2 Max Delbrück Center for Molecular Medicine in the Helmholtz Association (MDC), Robert-Rössle-Str. 10, 13125 Berlin, Germany

3 Experimental and Clinical Research Center, a joint cooperation between the Charité Medical Faculty and the Max Delbrück Center for Molecular Medicine, Berlin, Germany

4 DZHK (German Centre for Cardiovascular Research), partner site Berlin, Berlin, Germany

5 College de France, Paris, France

6 Charite University Medicine Berlin, Berlin, Germany

7 Institute for Biology, University of Lübeck, Lübeck, Germany

\section{Introduction}

The (pro)renin receptor $((\mathrm{P}) \mathrm{RR})$ was identified as the receptor for (pro)renin and renin [45, 67]. However, (P)RR expression is found also in organisms lacking a renin-angiotensin system suggesting additional functions [33, 46, 66, 67]. The (P)RR is an essential adaptor protein in the canonical Wnt signaling pathway [15] and participates also in non-canonical Wnt signaling [9, 10, 23-26]. In humans, mutations in (P)RR cause epilepsy and intellectual impairment [58].

Part of the (P)RR has been recognized to be identical to the M8-9 protein, a potential accessory subunit of $\mathrm{H}^{+}$-ATPases and (P)RR is thus also known as ATP6ap2 [36]. Additional studies confirmed protein-protein interactions between the (P)RR/ATP6ap2 and $\mathrm{H}^{+}$-ATPases [41].

$\mathrm{H}^{+}$-ATPases are multi-subunit complexes that mediate the transport of protons driven by hydrolysis of ATP. $\mathrm{H}^{+}$-ATPases are composed of a membrane bound $\mathrm{V}_{0}$ domain and a cytoplasmic $\mathrm{V}_{1}$ domain. Its location is mainly in intracellular organelles like endosomes, 
lysosomes, golgi apparatus, and secretory vesicles but it can also be found in the plasma membrane in organs like the kidney, epididymis, and bone $[8,71] . \mathrm{H}^{+}$-ATPases are fundamental for acidification of late endosomes and lysosomes allowing membrane trafficking, protein degradation, and protein maturation [19, 37, 71]. ATP6ap2 shares $\mathrm{H}^{+}$-ATPase location in the plasma membrane of renal and other cells $[1,17,30,59]$ but also in intracellular organelles [63]. The importance of $\mathrm{H}^{+}$-ATPases in endocytosis has been further confirmed in studies in mice lacking the $\mathrm{V}_{0}$ domain $\mathrm{H}^{+}$-ATPase a4 subunit in the kidney [22, 48]. These animals presented a generalized impairment of proximal tubule functions with glycosuria, phosphaturia, and lysosomal defects. Similarly, humans and mice with mutations or loss of the ClC-5 chloride/proton exchanger, critical for lysosomal acidification and thought to work in tandem with endosomal and lysosomal $\mathrm{H}^{+}$-ATPases, show impaired endocytosis and lysosomal function [14, $53,73]$. Also in other organs, $\mathrm{H}^{+}$-ATPase-mediated acidification of lysosomes and autophagosomes is critical for their function [20].

ATP6ap2 has been also linked to endocytosis in mouse and drosophila models. Conditional knockout mice for ATP6ap2 in podocytes and cardiomyocytes exhibit accumulation of autophagic vesicles suggesting lysosomal defects $[49,59]$. In addition, embryonic fibroblast and podocyte cells in which ATP6ap2 was deleted showed a downregulation of several $\mathrm{V}_{0} \mathrm{H}^{+}$-ATPase subunits [30]. In drosophila, deletion of ATP6ap2 impaired Wnt signaling by reducing endosomal recycling of frizzled-related receptors, and reduced fluid-phase endocytosis, both functions linked to reduced $\mathrm{H}^{+}$-ATPase activity [25].

The kidney proximal tubule is among the most active endocytic tissues reabsorbing a large variety of proteins, small peptides, and peptidomimetic drugs via receptormediated and fluid-phase endocytosis [47]. Receptor-mediated endocytosis requires the presence and function of the endocytic receptors megalin and cubilin expressed in the brush border membrane and endocytic apparatus. Moreover, efficient acidification of the endocytic pathway is critical for recycling and processing of proteins, activation of lysosomal enzymes and transporters, and lysosomal signaling via the mammalian target of rapamycin (mTOR) pathway [40, $65,68]$. Several of these processes have been shown to be $\mathrm{H}^{+}$-ATPase dependent $[34,37]$.

To date, the role of ATP6ap2 in the proximal tubule has not been elucidated. Here, we investigated ATP6ap2 function in proximal tubule using two different animal models. A rat model with an inducible shRNA for Atp6ap2 and an inducible kidney-epithelial cell-specific knockout mouse for ATP6ap2. We report that ATP6ap2 plays a role in cargo reabsorption and processing via receptor-mediated endocytosis, hence, contributing to kidney proximal tubule function.

\section{Methods}

\section{Animals}

\section{Generation and breeding of transgenic Atp6ap2 shRNA rats}

Transgenic rats were generated as described previously [32]. Briefly, complementary sense and antisense oligonucleotides (rAtp6ap2sh3: 5'- TCC CCC TAC AAC CTT GCG TAT AAT TCA AGA GAT TAT ACG CAA GGT TGT AGG TTT TTT A -3' and rAtp6ap2sh4: 5'- CGC GTA AAA AAC CTA CAA CCT TGC GTA TAA TCT CTT GAA TTA TAC GCA AGG TTG TAG G $-3^{\prime}$ ) specifically targeting a sequence in the exon 9 of the rat (P)RR/Atp6ap2 mRNA were annealed and cloned into the bimodal pINV7 vector (Taconic) using the BbsI and MluI restriction sites.

To generate transgenic rats, a $4 \mathrm{~kb}$ DNA fragment containing pTet-shAtp6ap2 (Fig. 1A) was cut out with the PacI and KpnI restriction enzymes, purified from the gel using a Wizard® SV Gel and PCR Clean-Up System (Promega), dissolved at $3 \mathrm{ng} / \mu \mathrm{l}$ with microinjection buffer $(8 \mathrm{mM}$ Tris-HCl, $\mathrm{pH} 7.4$, and $0.15 \mathrm{mM}$ EDTA) and microinjected into fertilized oocytes of Sprague-Dawley (SD) rats according to established techniques [54]. Integration of the transgene was detected by PCR in genomic DNA isolated from tail biopsies with the primers TetOfw: 5' -TGC ATG TCG CTA TGT GTT CT -3 ' and CAGGSrv: 5'- TGG CGT TAC TAT GGG AAC AT - 3 '. Using one positive newborn, the transgenic line ShAtp6ap2 was then established on the SD background. Negative littermates were used as wild type (Wt) controls.

Rats were maintained in individually ventilated cages under standardized, pathogen-free conditions (at a temperature of $21 \pm 2{ }^{\circ} \mathrm{C}$, humidity of $65 \pm 5 \%$, and with an artificial 12-h light/dark cycle) with free access to standard chow $(0.25 \%$ sodium; SSNIFF) and drinking water ad libitum. All animal care and experiments were performed in accordance with the institutional guidelines of German Federal Law and local authorities of Berlin (LaGeSo).

\section{Doxycycline treatment of rats in vivo}

To induce expression of shRNA against ATP6ap2, animals were treated with $0.5 \mathrm{~g} / \mathrm{l}$ doxycycline (Sigma) in the drinking water for 8 days. The doxycycline water was freshly prepared each day and kept dark due to the light sensitivity. To confirm the functionality of the system, ATP6ap2 protein and RNA levels were analyzed in organs by western blot and real-time PCR, respectively. 


\section{A}

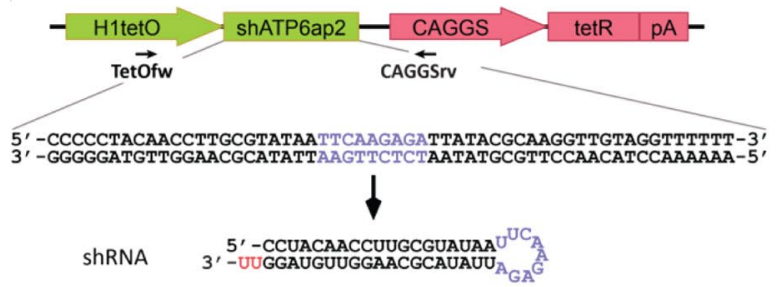

C

$$
\frac{\text { Heart }}{W t} \frac{\text { Lung }}{W_{t} \text { Sh }} \frac{\text { Liver }}{W t ~ S h} \frac{\text { Kidney }}{W_{t} \text { Sh }} \frac{\text { Spleen }}{W_{t} \text { Sh }} \frac{\text { Muscle }}{W t ~ S h}
$$

TetR

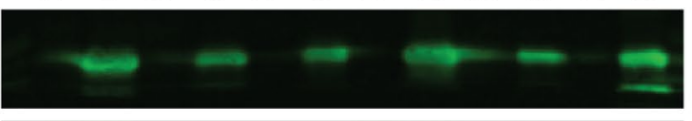

Gapdh

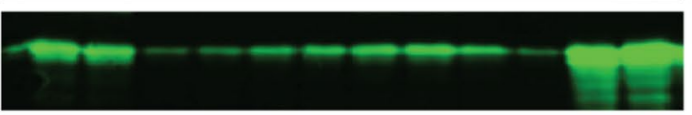

$E$
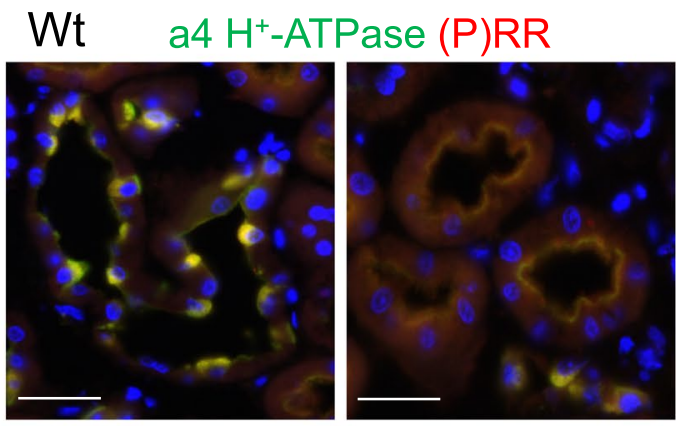

Sh
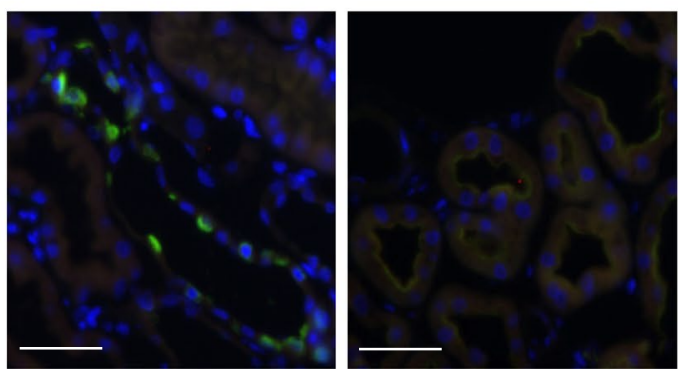

Fig. 1 Generation of the Atp6ap2 shRNA rat model and efficiency of Atp6ap2/(P)RR) knock-down. A Structure of the transgene construct, pTet-sh, made of two expression cassettes. A first one carries a tetracycline operator (tetO) sequence and expresses an shRNA against Atp6ap 2 under the control of the human $\mathrm{H} 1$ promoter. A second cassette consists of a tetracycline repressor (tetR) cDNA followed by a polyadenylation site (pA), and is driven by the CAGGS promoter. Primers TetOfw and CAGGSrv (arrows) were used for genotyping of rats. B Genotyping by PCR performed on newborn rat tails with a 195-bp PCR product characteristic of the transgenic animals (Sh). C Comparative expression of tetracycline repressor (TetR) protein

\section{B}

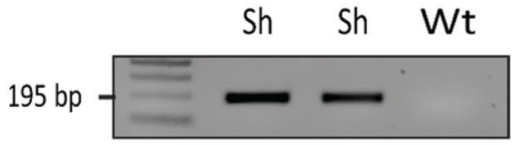

D

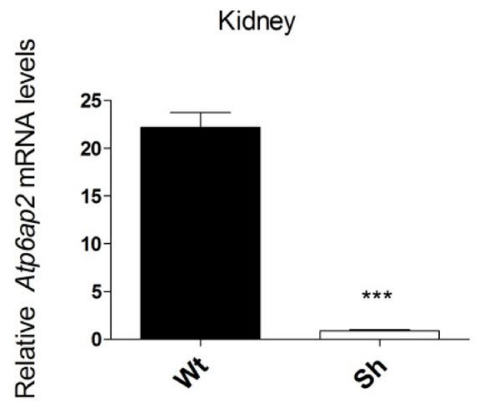

$\mathrm{F}$

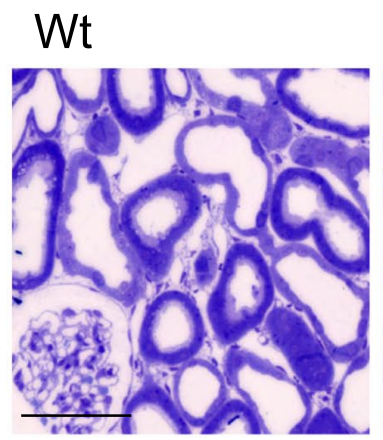

Sh

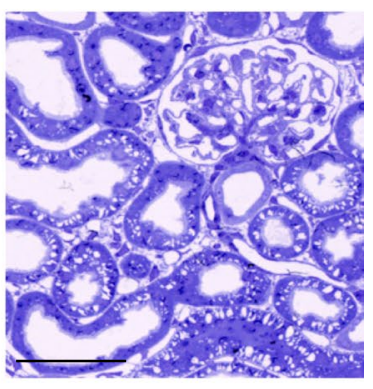

between transgenic (Sh) and control $(\mathrm{Wt})$ rats, as studied in various tissues by western blot. GAPDH was used as loading control. D RTqPCR analysis of total mRNA of kidneys from rat Wt and Sh demonstrates successful knock-down of (P)RR/Atp6ap2 mRNA ( $\mathrm{n}=6$ /genotype). E Immunohistochemistry for the $\mathrm{H}^{+}$ATPase a4 subunit (green), ATP6ap2 (red), and DAPI (blue) in kidney sections from Wt and Sh rats. Yellow overlay is seen in the Wt sections due to colocalization of a4 and ATP6ap2 while in sections from Sh rats only green staining for a4 is visible. Scale bar size: $50 \mu \mathrm{m}$. F Renal morphology of Sh and control animals. Semi-thin Sect. (200 nm thick) were stained with Toluidine Blue, scale bar size $100 \mu \mathrm{m}$ 


\section{Western blotting to confirm shAtp6ap2 rats}

Rats were anesthetized with isoflurane followed by exsanguination. Tissues were collected, snap frozen in liquid nitrogen, coarsely ground using a mortar and pestle, and further homogenized in RIPA buffer (Cell Signaling) for protein extraction, using a FastPrep ${ }^{\mathrm{TM}}-24$ (MP Biomedicals) according to the manufacturer's instructions. Total proteins were added to $4 \times$ Roti ${ }^{\circledR}$-load buffer (Carl Roth) and separated by $12 \%$ SDS/PAGE. Proteins were then blotted on a PVDF membrane (Amersham Biosciences), which was subsequently blocked with Odyssey ${ }^{\circledR}$ Blocking Buffer and incubated with the following primary antibodies: mouse antiTetR (1:8000, MoBiTec) and rabbit anti-GAPDH (1:1000, Cell Signaling). Protein revelation was performed with an Odyssey ${ }^{\circledR}$ Infrared imaging system (LI-COR Biosciences) using IRdye ${ }^{\circledR} 800$-coupled secondary antibodies $(1: 10,000$, LI-COR Biosciences).

\section{Kidney-epithelial cell-specific ATP6ap2 KO mice generation}

The generation and genotype of ATP6ap $2^{\text {flox/y }}$ has been already described [59]. Heterozygous ATP6ap $2^{\text {flox/x }}$ females were crossed with males both positive for Pax8-rtTA and Cre [44, 69]. Expression of Cre-recombinase was induced in male ATP6ap2 $2^{\text {flox/y,Pax8Cre+ }}$ and ATP6ap2 $2^{+/+, P a x 8 C r e+}$ transgenic mice by $1 \mathrm{mg} / \mathrm{mL}$ of doxycycline (Sigma) in drinking water containing $2 \%$ of Sucrose (Sigma) for 5 days followed by 5 days induction with $0.25 \mathrm{mg} / \mathrm{mL}$ doxycycline in $2 \%$ sucrose drinking water and 4 days without doxycycline [44]. A second group of ATP6ap2 $2^{\text {flox/y,Pax8Cre+ }}$ and ATP6ap2 $2^{+/+ \text {Pax } 8 \text { Cre+ }}$ transgenic mice received $2 \mathrm{mg} / \mathrm{mL}$ doxycycline for 5 days followed by 5 days of $1 \mathrm{mg} / \mathrm{mL}$ doxycycline in water containing $2 \%$ sucrose [69]. These groups are accordingly referred to as $1 \mathrm{mg}$ and $2 \mathrm{mg}$ doxycycline. Animals used for experiments were 2- to 3-month-old male mice bred in a C57BL/6 background. All animal studies were performed according to Swiss welfare laws and with approval of the local veterinary authorities.

\section{Plasma and urine analysis}

Blood was collected from the tail vein of anesthetized rats and vena cava from anesthetized mice. Heparinized blood was centrifuged at $7000 \mathrm{rpm}$ for $7 \mathrm{~min}$, plasma collected, and rapidly frozen. Measurements of blood $\mathrm{pH}$ and blood electrolyte concentrations $\left(\mathrm{Na}^{+}, \mathrm{K}^{+}, \mathrm{Cl}^{-}, \mathrm{Ca}^{2+}\right)$ were analyzed using an ABL80 FLEX CO-OX (Radiometer, Copenhagen) and performed on heparinized tail vein blood. Urine was collected under mineral oil for $24 \mathrm{~h}$ in metabolic cages (Tecniplast ${ }^{\circledR}$, Italy) and aliquots were rapidly frozen and stored at $-80{ }^{\circ} \mathrm{C}$ until measurement. Urine and plasma laboratory analyses were performed in the Zurich Integrative Rodent Physiology (ZIRP) core facility.

\section{RNA extraction and RT-qPCR}

Harvested organs were snap frozen in liquid nitrogen. Total RNA was extracted using the Qiagen RNeasy Mini Kit (Qiagen, Hombrechtikon, Switzerland). Snap-frozen tissue slices were homogenized in a pestle homogenizer (Potter-Elvehjem type) together with $1 \mathrm{~mL}$ precooled RLT-Buffer supplemented with $\beta$-mercaptoethanol at a final concentration of $1 \%$. Subsequently, $350 \mu \mathrm{l}$ of the homogenate was used for RNA preparation carried out according to the manufacturer's instructions. DNase digestion was performed using the RNase-free DNase Set (Qiagen; Hilden, Germany). Total RNA extractions were analyzed for quality, purity, and concentration using the NanoDrop ND-1000 spectrophotometer (Wilmington, DE, USA). RNA samples were diluted to a final concentration of $100 \mathrm{ng} / \mu \mathrm{l}$ and cDNA was prepared using the TaqMan Reverse Transcriptase Reagent Kit (Applied Biosystems, Roche; Forster City, CA, USA). In brief, in a reaction volume of $40 \mu \mathrm{l}, 100 \mathrm{ng}$ of RNA was used as template and mixed with the following final concentrations of RT buffer $(1 \mathrm{x}), \mathrm{MgCl}_{2}(5.5 \mathrm{mM})$, random hexamers $(2.5 \mu \mathrm{M})$, dNTP mix (500 $\mu \mathrm{M}$ each), RNase inhibitor $(0.4 \mathrm{U} / \mu \mathrm{l})$, multiscribe reverse transcriptase $(1.25 \mathrm{U} / \mu \mathrm{l})$, and RNAse-free water. Reverse transcription was performed with thermocycling conditions set at $25^{\circ} \mathrm{C}$ for $10 \mathrm{~min}, 48^{\circ} \mathrm{C}$ for $30 \mathrm{~min}$, and $95^{\circ} \mathrm{C}$ for $5 \mathrm{~min}$ on a thermocyler (Biometra, Goettingen, Germany).

Semi-quantitative real-time PCR (RT-qPCR) was performed on the ABI PRISM 7700 Sequence Detection System (Applied Biosystems). Primers for Atp6ap2 were designed using Primer Express software from Applied Biosystems and purchased from Microsynth, Switzerland. Probes were labelled with the reporter dye FAM at the 5 '-end and the quencher dye TAMRA at the 3'-end (Microsynth, Balgach, Switzerland).

For Mus musculus RT-qPCR, the following pair of primers for Atp6ap2 was used: forward 5'-GTGCTGGTCGTT CTCCTGTTC- 3'; reverse 5'-GGGATTCGATCTCCTGGT ATAG- $3^{\prime}$ together with a probe 5'GTGGCGGGTGCTTTA GGGAATGAAT- $3^{\prime}$ which target only Atp6ap 2 exon 2. For Rattus norvegicus Atp6ap2 RT-qPCR, we used: forward 5'-TCGGATCCTTGTTGATGCTCTC -3'; reverse 5'- CTC ACCAGGGATGTGTCGAA- $3^{\prime}$ primers and 5'- TGGGAA TGCAGTGGTAGAGTTGGTGA $-3^{\prime}$ as probe. Real-time PCR reactions were performed using TaqMan Universal PCR Master Mix (Applied Biosystems) as described in the manufacturer's user manual. 


\section{Protein extraction and immunoblotting}

Crude membrane and cytosolic proteins were extracted from half a kidney. Briefly, organs were homogenized in $200 \mu \mathrm{l}$ of ice-cold resuspension buffer (200 mM Mannitol, 80 mM HEPES, $41 \mathrm{mM} \mathrm{KOH,} \mathrm{pH} 7.5$ supplemented with 1 tablet/10 mL Complete Mini Protease Inhibitor Cocktail, Roche) using a Polytron homogenizer $(0.5 \mathrm{~mm}$ diameter at $20,000 \mathrm{rpm}$ for $1 \mathrm{~min}$ at $4{ }^{\circ} \mathrm{C}$ ). The homogenate centrifuged at $2000 \mathrm{rpm}$ for $20 \mathrm{~min}$ at $4{ }^{\circ} \mathrm{C}$. The resulting supernatant was further centrifuged at $41,000 \mathrm{rpm}$ for $1 \mathrm{~h}$ at $4{ }^{\circ} \mathrm{C}$. Brush border membrane protein preparation was performed according to the $\mathrm{Mg}^{2+}$ precipitation procedure [6].

Tissue and urine samples were normalized for protein or creatinine levels, respectively, diluted in Laemmli buffer, heated at $95^{\circ}$ for $5 \mathrm{~min}$, and separated by SDS-polyacrylamide gels electrophoresis on $8-12 \%$ gels. For immunoblotting, proteins were transferred to polyvinylidene fluoride membranes (Immobilon-P, Millipore, Bedford, MA, USA). After blocking with 5\% milk powder in Tris-buffered saline/ $0.1 \%$ Tween-20 for $30 \mathrm{~min}$, blots were incubated with the primary antibodies: rabbit antiATP6V0a4 serum (1:1000) [72], rabbit anti-ATP6V0a2 (a kind gift of Dr. X. S. Xie, Dallas, TX, USA) [51, 64], rabbit anti-ATP6V1B2 serum (1:5000 raised against the sequence EFYPRDSAKH, Pineda Berlin, Germany), mouse monoclonal anti-ATP6V1E2 (1:1000, a kind gift of Dr. S. L Gluck, University of California, San Francisco, CA,USA) [4], rabbit polyclonal anti-NaPi-IIa (1:5000) [16], sheep anti-Megalin (1:10.000, a kind gift from Dr. Erik Ils $\varnothing$ Christensen, Aarhus University, Denmark) [42], rabbit anti-cubilin (1:1000, a kind gift from Dr. Erik Ilsø Christensen, Aarhus University, Denmark), rabbit anti-VDBP (1:2500, Dako, A0021), rabbit-human transferrin (1:2000, Dako, A0061), rabbit anti-NHE3 (1:1000, StressMarq,SPC-400D), rabbit anti-(P)RR (1:500, Sigma, HPA003156), mouse anti- $\mathrm{Na}^{+} / \mathrm{K}^{+}$ATPase $\alpha(\mathrm{H}-3)$ (1:5000, Santa Cruz, sc-48345), rabbit anti-mTOR (1:1000, \#2972, Cell Signaling Technology, Boston, MA, USA), rabbit anti-phospho-mTOR (1:1000, \#2974, Cell Signaling Technology, Boston, MA, USA), and mouse monoclonal anti- $\beta$-actin antibody (1:5000, A5441, Sigma), either for $2 \mathrm{~h}$ at room temperature or overnight at $4{ }^{\circ} \mathrm{C}$. Membranes were then incubated for $1 \mathrm{~h}$ at room temperature with secondary anti-rabbit or anti-mouse antibodies linked to alkaline phosphatase $(1: 10,000$, S373B, S372B, Promega, USA), or anti-sheep antibodies coupled to HRP (1:20,000, Dako, P0163), or anti-mouse HRP (1:20,000, W402B, Promega, USA). The protein signal was detected with the appropriate substrates using the LAS 4000 (Fujifilm) detection system. All images were analyzed using the software Quantity One 4.6.1 (Biorad) to calculate the protein of interest $/ \beta$-actin ratio.

\section{Immunofluorescence staining}

Mouse and rat kidneys were perfused in situ through the left heart ventricle with a solution containing 10,000 IU Heparin-Na Solution (B. Braun Medical AG, Sempach, Switzerland), $2 \mathrm{~mL}$ Lidocain 1\% (Streuli Pharma AG, Uznach, Switzerland), $2 \mathrm{~mL} \mathrm{CaCl}_{2}, 16 \%, 2 \mathrm{~mL} 0.9 \% \mathrm{NaCl}$, and $2 \mathrm{~mL}$ distilled water. Subsequently, animals were perfused with $3 \%$ paraformaldehyde in phosphate-buffered saline (PBS). Fixed kidneys were cryoprotected with $2.3 \mathrm{M}$ sucrose (Sigma), embedded in TissueTec OCT compound 4583 (Sakura Finetek USA, Torrance, CA), and frozen in liquid nitrogen and stored at $-80^{\circ} \mathrm{C}$. Kidney cryosections were cut with $5 \mu \mathrm{m}$ thickness on a Leica CM3050S cryostat (Leica Microsystems, Bannockburn, IL). Slides were rehydrated in PBS and treated either with $10 \mathrm{mM}$ Tris (Trizma Base, Sigma), $\mathrm{pH} 10$ at $100^{\circ}$ for $20 \mathrm{~min}$ in a pressure cooker (HistoPro, Millestone) or $10 \mathrm{mM}$ citric acid (Sigma), pH 6.0 at $98{ }^{\circ} \mathrm{C}$ for $20 \mathrm{~min}$ or $1 \%$ sodium dodecyl sulfate (SDS) in PBS. In the case of Lamp1 staining, slides were quenched with $50 \mathrm{mM}$ of $\mathrm{NH}_{4} \mathrm{Cl}$ in PBS, three times for $10 \mathrm{~min}$. Unspecific sites were blocked with a solution containing $1 \mathrm{X}$ PBS/5\% donkey serum (Sigma)/0.3\% Triton X-100 (Sigma) for $20 \mathrm{~min}$ at room temperature. Primary antibodies were diluted in $1 \mathrm{X}$ PBS/1\% BSA/0.3\% TritonX-100: goat polyclonal anti-(P)RR/ATP6AP2 (1:100, Novus Biologicals, NB1001318 , used with SDS pretreatment); rabbit polyclonal antiATP6IP2 antibody (1:200, ABCAM ab40790, used with microwaving in citric acid), goat polyclonal anti-(P)RR antibody (1:100, R\&D Systems, \#AF5716, used with SDS pretreatment), rabbit anti- ATP6V0a4 serum (1:2000) [72], goat anti-megalin (1:600, Santa Cruz, sc-16478), rabbit antihuman transferrin (1:600, Dako, A006), rabbit anti-cubilin (1:700, kindly provided by Dr. Erik Ils $\varnothing$ Christensen, Aarhus University, Denmark), rat anti-Lamp1 (1:1000, 1D4B was deposited to the DSHB by August, J.T. (DSHB Hybridoma Product 1D4B)), anti-rabbit LC3B (1:250, Cell Signaling Technology, \# 2775), goat anti-AQP2 (1:400, Santa Cruz), or rabbit anti-AQP2 (1:1000, kindly provided by Dr. J. Loffing, University of Zurich) and kidney sections were incubated with the primary antibodies overnight at $4{ }^{\circ} \mathrm{C}$. Sections were washed twice with hypertonic PBS $(18 \mathrm{~g} / \mathrm{l} \mathrm{NaCl} /$ PBS) and once with 1X PBS. Afterwards, sections were incubated with corresponding secondary antibodies (1:1000) (anti-goat Alexa594 and anti-goat Alexa488, anti-rat Alexa 647, anti-rabbit Alexa 488, and anti-rabbit Alexa594 (Invitrogen, Switzerland), phalloidin-Texas Red $®(1: 100$, Molecular Probes), phalloidin-A647 (1:1000, Abcam, ab176759), and DAPI (1:1000, Sigma-Aldrich, Buchs, Switzerland) for $1 \mathrm{~h}$ at room temperature. Slides were washed twice with 
hypertonic PBS and then once with $1 \mathrm{X}$ PBS before being mounted with Dako glycergel mounting medium. Semithin Sects. (200 nm thickness) were cut with an ultramicrotome (Leica Microsystems Leica EM FCS) and stained with Toluidine Blue O (T3260 Sigma-Aldrich). Semi-thin sections were visualized with slide-scanner Axio Scan.Z1 Zeiss, Objective Plan Apochromat 40x, NA 0.95 air (Zeiss Germany). Immunofluorescence sections were either visualized with a confocal laser scanning microscope (Zeiss LSM 700, Carl Zeiss) or a Leica DFC490 charged coupled device camera attached to a Leica DM 6000 fluorescence microscope (Leica, Wetzlar, Germany). The confocal microscope pinhole was set at 1 Airy unit and pixel size at $90 \mathrm{~nm}$ and a $40 \times / 1.3$ oil DIC M27 objective was used. Images were processed (overlays) using Adobe Photoshop and ImageJ software (http://rsb.info.nih.gov/ij/).

\section{Endocytic marker injection and tissue fluorescence measurement}

Dextran-FITC $10 \mathrm{kDa}$ (D1821, Molecular Probes) was used as fluid-phase endocytosis marker and human recombinant transferrin (T3795, Sigma) was used as receptor-mediator endocytosis marker [47]. Dextran-FITC and human transferrin were diluted in the same isotonic saline solution $(6.25 \mathrm{mg} / \mathrm{mL}$ for dextran-FITC and $50 \mathrm{mg} / \mathrm{mL}$ for transferrin) and injected into the tail vein. Cytoplasmic fractions for kidney protein extraction were used for measuring FITC in the tissue with Nanodrop 3300 Fluorospectrometer (ThermoScientific). Samples were normalized for protein content and blanked with a sample from an animal that was not injected.

\section{Statistical analysis}

Statistical significances were calculated by Student's t-test. $\mathrm{P}<0.05$ was considered significant. Results are presented as mean $\pm \mathrm{SEM}$.

\section{Results}

\section{Knock-down of Atp6ap2 in rats}

Transgenic rats (Sh rats) expressing an shRNA against Atp6ap2 were generated by inserting a transgene under the control of tetracycline repressor protein (TetR) allowing the controlled activation of the shRNA by doxycycline treatment (Fig. 1A). Integration of the transgene and expression of the TetR mRNA and protein was confirmed by PCR (Fig. 1B) and immunoblotting (Fig. 1C). We could detect TetR protein in all organs tested. Expression of the Atp6ap2 protein and mRNA were studied in more detail in the kidney from animals 10 days after doxycycline treatment. RT-qPCR for Atp6ap 2 mRNA in the whole kidney showed a decrease by approx. $90 \%$ of the transcript in Sh rats when compared with control rats (Wt) (Fig. 1D). Similarly, immunohistochemistry on kidney sections stained for the ATP6ap2 and the $\mathrm{H}^{+}$-ATPase subunit a4 (Fig. 1E) demonstrated greatly reduced or absent ATP6ap2-related staining in proximal tubule and intercalated cells. $\mathrm{H}^{+}$-ATPase subunit a4 staining was used as a positive control, since both proteins share the same localization in the kidney [17]. Thus, Atp6ap2 shRNA rats present with an efficient knock-down of Atp6ap2 mRNA and protein in the kidney.

At the level of light microscopy, similar overall renal morphology was seen in $\mathrm{Wt}$ and Sh rats (Fig. 1F). However, in Sh rat kidneys, we could observe some areas containing vacuoles, suggesting degeneration of some nephrons. Such areas were less seen in Wt kidneys. The gross morphology of glomeruli was undistinguishable between $\mathrm{Wt}$ and $\mathrm{Sh}$ rats unlike in mice with podocyte-specific deletion of the ATP6ap2 [49, 59].

Body weight, food and water intake, was not different in $\mathrm{Wt}$ and Sh rats 10 days after doxycycline treatment. Urine and blood analysis revealed normal electrolytes and $\mathrm{pH}$. BUN and blood phosphate levels were elevated in Sh rats whereas creatinine clearance decreased consistent with a mild impairment of renal function. In urine, sodium levels were lower while phosphate and creatinine excretion was increased in Sh rats (Table 1).

\section{ATP6ap2 knock-down impairs proximal tubule receptor-mediated endocytosis}

Sh rats exhibited mild albuminuria and low molecular weight proteinuria as indicated by elevated vitamin $\mathrm{D}$ binding protein (VDBP) in urine (Fig. 2A,B). To further determine which endocytic pathway may be impaired, we coinjected in both animal groups a marker for fluid endocytosis (dextran-FITC, $10 \mathrm{kDa}$ ) and a marker for receptormediated endocytosis (human transferrin) and fixed kidneys for immunohistochemistry 10 and 40 min after injection. Dextran-FITC was co-stained with phalloidin (marker for the brush border membrane) to allow subcellular determination of dextran localization. By fluorescence microscopy, no differences were observed in FITC intensity or subcellular localization between animal groups at $10 \mathrm{~min}$. In addition, the relative amount of FITC in kidney tissue at 10 min was similar between animal groups (Fig. 2C,D). Dextran-FITC at 40 min was also analyzed (Supplementary Fig.1) and staining intensity was weaker than at 10 min but showed similar subcellular localization in both genotypes. Thus, fluid-phase endocytosis was not affected by (P)RR/AT6ap2 knock-down.

In contrast, endocytosis of human transferrin was altered in $\mathrm{Sh}$ rats compared to $\mathrm{Wt}$ animals. We used antibodies 
Table 1 Metabolic and urine parameters from Wt and Sh rats. Water and food intake and urine volume were monitored in metabolic cages under baseline conditions. After adaptation, $24 \mathrm{~h}$ urine and blood were collected for analysis. Statistical analysis was performed using Student's $t$-test $(\mathrm{n}=6 /$ genotype $) * \mathrm{p}<0.05, * * \mathrm{p}<0.01, * * \mathrm{p}<0.001$

\begin{tabular}{|c|c|c|}
\hline Parameters & Wt & Sh \\
\hline Body weight (g) & $303.8 \pm 10.7$ & $268.1 \pm 18.7$ \\
\hline $\mathrm{H}_{2} \mathrm{O}$ intake $(\mathrm{g} / \mathrm{g} \mathrm{BW})$ & $0.13 \pm 0.01$ & $0.13 \pm 0.01$ \\
\hline Food intake (g/g BW) & $0.09 \pm 0.01$ & $0.09 \pm 0.01$ \\
\hline \multicolumn{3}{|l|}{ Plasma } \\
\hline $\mathrm{pH}$ & $7.47 \pm 0.01$ & $7.51 \pm 0.02$ \\
\hline Glucose (mg/dL) & $225.8 \pm 22.2$ & $206.8 \pm 16.6$ \\
\hline $\mathrm{Na}^{+}(\mathrm{mM})$ & $136.5 \pm 1.0$ & $136.2 \pm 0.3$ \\
\hline $\mathrm{K}^{+}(\mathrm{mM})$ & $4.37 \pm 0.15$ & $3.62 \pm 0.22$ \\
\hline Ionized $\mathrm{Ca}^{2+}(\mathrm{mM})$ & $0.84 \pm 0.14$ & $0.80 \pm 0.05$ \\
\hline $\mathrm{Cl}^{-}(\mathrm{mM})$ & $97.8 \pm 0.8$ & $95.7 \pm 0.6$ \\
\hline Phosphate (mg/dL) & $8.6 \pm 0.4$ & $9.8 \pm 0.3 *$ \\
\hline Prealbumin (mg/dL) & $1.72 \pm 0.31$ & $1.53 \pm 0.22$ \\
\hline Creatinine (mg/dL) & $0.30 \pm 0.02$ & $0.40 \pm 0.01$ \\
\hline BUN (mg/dL) & $35.2 \pm 1.0$ & $48.3 \pm 2.6 * * *$ \\
\hline \multicolumn{3}{|l|}{ Urine } \\
\hline Urine (g/g BW) & $0.04 \pm 0.01$ & $0.03 \pm 0.01$ \\
\hline Creatinine (mg/dL) & $72.2 \pm 10.3$ & $111.9 \pm 13.2 *$ \\
\hline Creatinine Clearance (mL/min) & $1.9 \pm 0.2$ & $1.5 \pm 0.2$ \\
\hline $\mathrm{Na}^{+}(\mathrm{mM}) / \mathrm{Crea}(\mathrm{mg} / \mathrm{dL})$ & $95.0 \pm 8.3$ & $71.2 \pm 22.8 * *$ \\
\hline $\mathrm{K}^{+}(\mathrm{mM}) / \mathrm{Crea}(\mathrm{mg} / \mathrm{dL})$ & $2.60 \pm 0.11$ & $2.73 \pm 0.14$ \\
\hline $\mathrm{Ca}^{2+}(\mathrm{mM}) / \mathrm{Crea}(\mathrm{mg} / \mathrm{dL})$ & $0.020 \pm 0.003$ & Not detectable \\
\hline $\mathrm{Mg}^{2+}(\mathrm{mg} / \mathrm{dL}) / \mathrm{Crea}(\mathrm{mg} / \mathrm{dL})$ & $0.57 \pm 0.10$ & $0.32 \pm 0.15$ \\
\hline Phosphate (mg/dL)/Crea (mg/dL) & $0.08 \pm 0.08$ & $1.71 \pm 0.20 * * *$ \\
\hline $\mathrm{Cl}^{-}(\mathrm{mM}) / \mathrm{Crea}(\mathrm{mg} / \mathrm{dL})$ & $2.2 \pm 0.1$ & $2.1 \pm 0.1$ \\
\hline
\end{tabular}

recognizing human but not endogenous rat or mouse transferrin and detected a weaker transferrin-related staining in kidneys from Sh rats $10 \mathrm{~min}$ after injection whereas $40 \mathrm{~min}$ after injection more pronounced staining was found in Sh rat kidneys than in Wt kidneys (Fig. 2E). At 10 min, transferrin was localized in the subapical region and presented as a punctuated pattern as expected [13]. Immunoblotting for human transferrin in urine samples collected 10 min after transferrin injection showed abundant transferrin in urine from Sh rats but very low levels in Wt urine suggesting reduced uptake (Fig. 2F). Forty minutes after injection, in Wt rats, transferrin staining was almost absent while in the $\mathrm{Sh}$ rats, transferrin staining accumulated in the perinuclear region (Fig. 2E).

The localization of the two major endocytic receptors megalin and cubilin was similar in both genotypes at light microscopy level (Fig. 2E and supplementary Fig. 2). The relative amount of megalin protein was unchanged whereas cubilin was more abundant in kidneys from Sh rats (Fig. 3).

ATP6ap2 was suggested to be an accessory subunit of $\mathrm{H}^{+}$-ATPases $[31,36,67]$ therefore a loss of ATP6ap2 could affect $\mathrm{H}^{+}$-ATPase regulation and/or function in the endocytic pathway. Immunoblotting showed reduced a $4 \mathrm{H}^{+}$-ATPase (ATP6V0a4) subunit whereas B2 (ATP6V1B2) and A (ATP6V1A) subunits were unaltered (Fig. 3).

The abundance of NaPi-IIa, the main phosphate transporter in the proximal tubule, and NHE3 (sodium-proton exchanger 3 ) is directly or indirectly affected by alterations in the endocytic apparatus of the proximal tubule $[2,3,18]$ NaPi-IIa showed no differences in abundance and NHE3 a slight increase in expression, however, not reaching significance due to high interindividual variability (Fig. 3).

\section{Kidney-epithelial cell-specific ATP6ap2 KO mice}

Since Atp6ap2 shRNA rats present with a full-body knockdown of the ATP6p2 that may impact on overall renal function and that complicates interpretation of data, we decided to examine proximal tubular endocytosis in a kidney-epithelial cell-specific inducible ATP6ap2 knockout (KO) mouse model using the well-described doxycycline-inducible Pax8-Cre system after crossing with floxed ATP6ap2 mice. First, we used a milder induction protocol for Cre activity [44] as usual based on previous experience suggesting that higher doses of doxycycline can also produce effects in wildtype mice and with the intention to downregulate ATP6ap2 mostly in proximal tubules without producing the strong phenotype caused by deletion of ATP6ap2 in the collecting duct $[56,57,70]$. However, to rule out that the milder doxycycline protocol ( $1 \mathrm{mg} / \mathrm{mL}$ induction), was too weak to reveal a proximal tubule role of ATP6ap2, we used in a second and independent series of animals also the conventional doxycycline protocol with $2 \mathrm{mg} / \mathrm{mL}$ induction. As detailed below, the findings in both series are qualitatively very similar and we report data from the first series in the main body of this manuscript. The data from the second series are presented in the supplementary files. To verify kidney-specific ATP6ap2 deletion, we performed RT-qPCR for Atp6ap2 in the kidney, lung, and heart (Fig. 4A and supplementary Fig. 3). Atp6ap2 was downregulated in both protocols only in kidneys from Flox/Pax $8+$ mice but not in other organs or kidneys from control Wt/Pax $8+$ mice. Western blotting using total kidney protein homogenate confirmed reduction of ATP6ap2 protein expression by about 50-75\% (Fig. 4B, suppl. Figure 3). Residual mRNA and protein expression may be due to expression in renal cells negative for Pax8 (i.e., podocytes) or incomplete deletion in epithelial cells. Immunohistochemistry using three different antibodies against ATP6ap2 demonstrated almost complete deletion of ATP6ap2 from proximal tubules but widely preserved staining in intercalated cells of the connecting tubule and medullary collecting ducts (Fig. 4C and supplementary Figs. 6 and 7). We noted major differences in specificity of commercial 
Fig. 2 Preserved fluid-phase endocytosis but impaired receptor-mediated endocytosis in (P)RR/ATP6ap2 deficient rats. A Albuminuria in Sh rats detected by Coomassie blue staining of SDS-Page gels loaded with urine samples normalized to creatinine $(7 \mathrm{mg} / \mathrm{mL})$ BSA $(7 \mathrm{mg} / \mathrm{mL})$ was loaded as positive control. Bar graph summarizing data $(n=4$ in each animal group). Student's $t$-test $* \mathrm{p}<0.05$. B Elevated vitamin $\mathrm{D}$ binding protein (VDBP) in urine of Sh rats detected by immunoblotting of urine samples normalized to creatinine (7 mg/mL). Bar graph summarizing data from $n=4 /$ genotype. C Immunohistochemistry for dextran-FITC (10 kDa, green), DAPI (blue), and actin/phalloidin (red) in kidney slices from Wt and shRNA rat 10 min after injection (scale bar size $50 \mu \mathrm{m}$ ). D Quantification of dextranFITC in the cytoplasmic fraction of the control and Sh rats kidney homogenate. FITCdextran was normalized to total protein content. E Immunohistochemistry for human transferrin (red), megalin (green), and DAPI (blue) in Wt and Sh rats kidney $10 \mathrm{~min}$ and $40 \mathrm{~min}$ after injection showed strong residual staining of transferrin after $40 \mathrm{~min}$ in Sh rat kidneys (see insert) (scale bar size $50 \mu \mathrm{m}$ ). F Western blotting for human transferrin in Wt and Sh rat urine $10 \mathrm{~min}$ after injection. Urine samples were normalized to creatinine $(7 \mathrm{mg} / \mathrm{mL})$. Bar graph summarizing data from $n=4 / g e n o t y p e$. Statistical analyses were performed using Student's $t$-test $* * \mathrm{p}<0.01$

A

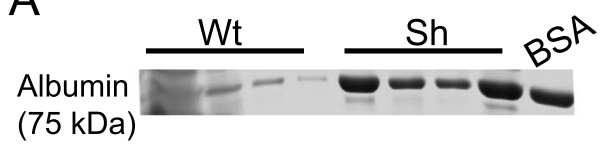

B

(75 kDa)

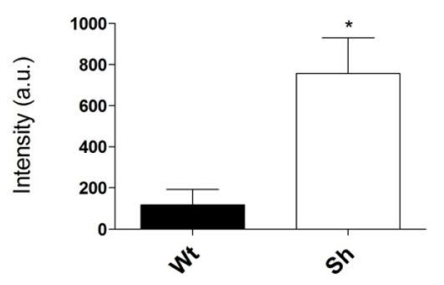

C wt

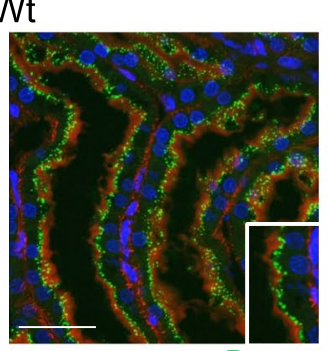

Sh

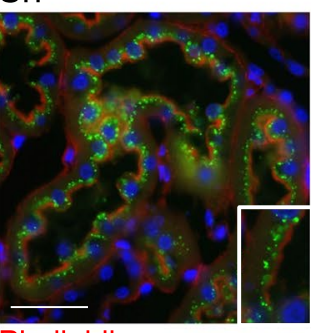

Dextran Phalloidin

E
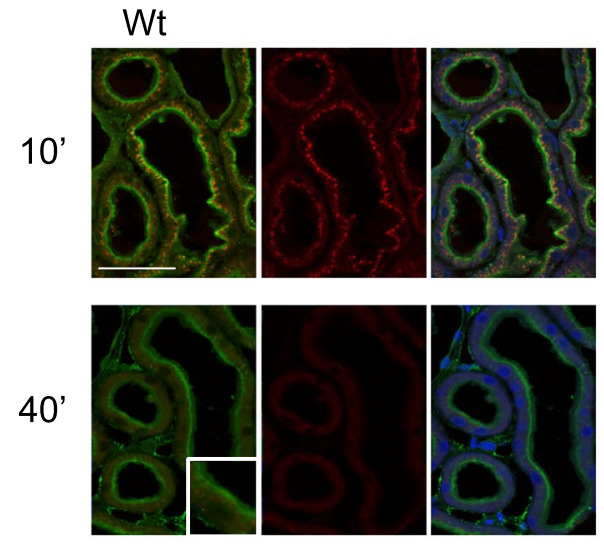

Megalin Transferrin DAPI
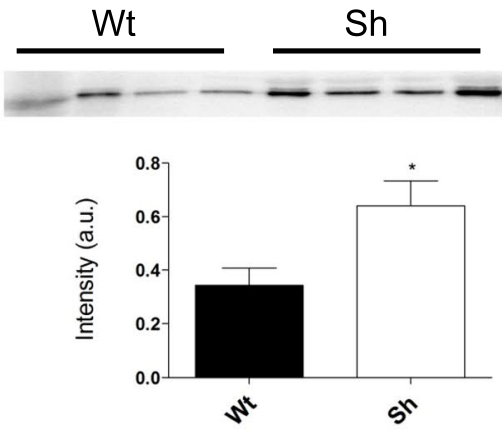

D

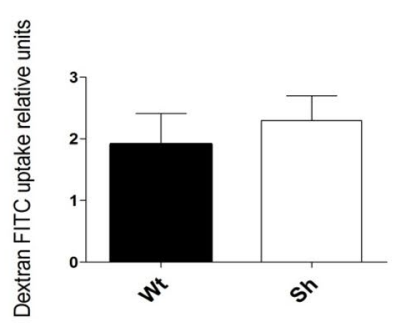

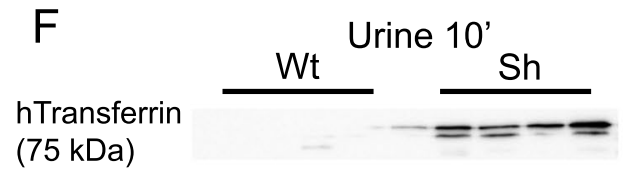

Sh
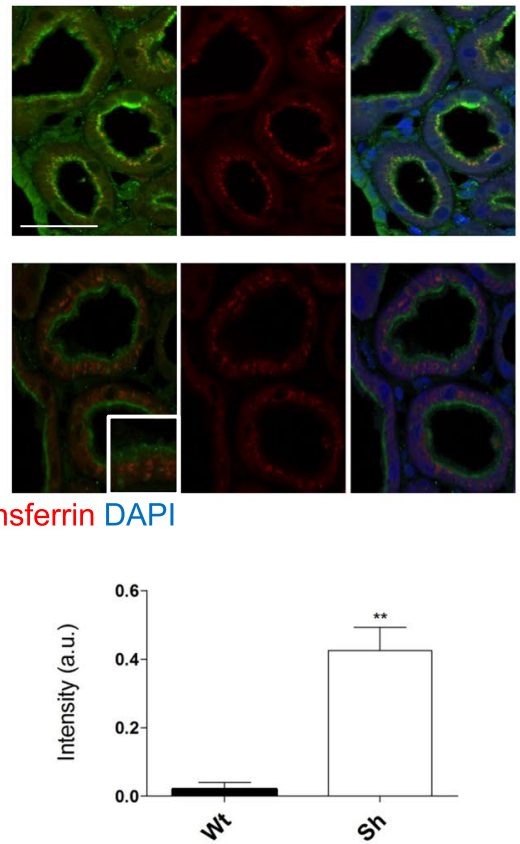

antibodies against ATP6ap2 as shown in Fig. 4 and suppl. Figures 7 and 8.

Flox/Pax $8+$ mice with the first, lower doxycycline protocol had normal blood acid-base and electrolyte status and no evidence for reduced kidney function unlike rats. Urine analysis showed higher diuresis and mild sodium and potassium losses with reduced urinary calcium excretion consistent with the deletion of the ATP6ap2 mostly from proximal tubules (Table 2). Mice receiving the higher doxycycline dose had mildly elevated plasma creatinine levels but otherwise normal plasma values including BUN. Urine data showed similar urine $\mathrm{pH}$ but reduced creatinine clearance in Flox/Pax $8+$ mice (supplementary table 1). Thus, Flox/Pax $8+$ with the higher doxycycline protocol showed some signs of renal impairment. 
Fig. 3 Altered expression of proteins involved in receptormediated endocytosis. A Brush border membrane preparations of control and Sh rat kidneys were used for blotting for $\mathrm{H}^{+}$ATPase a4 (ATP6V0a4), B2 (ATP6V1B2), and A (ATP6V1A) subunits as well as for NaPiIIa, NHE3, megalin, and cubilin. B Densitometries were adjusted to $\beta$-actin (loading control). Statistical analysis using Student's $t$-test $(\mathrm{n}=6$ / genotype or $n=4 /$ genotype for NaPiIIa). $* \mathrm{p}<0.05 * * * \mathrm{p} \leq 0.001$
A

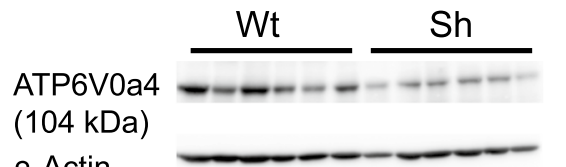

$\beta$-Actin

ATP6V1B2 (58 kDa)

$\beta$-Actin

ATP6V1A - - - - - - - (100 kDa) $\beta$-Actin

NHE3

(85 kDa)

$\beta$-Actin

Actin

$\beta$-Actin

Megalin

(600 kDa)

Cubilin

(460 kDa)
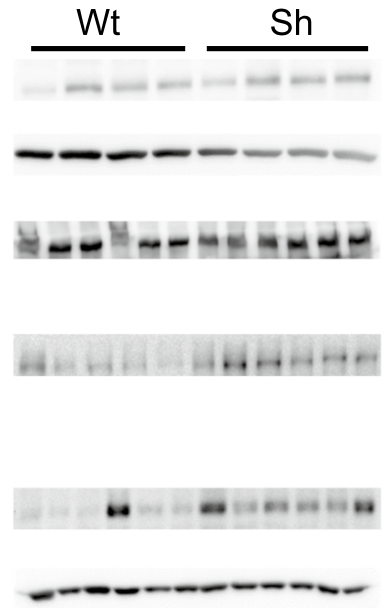

B
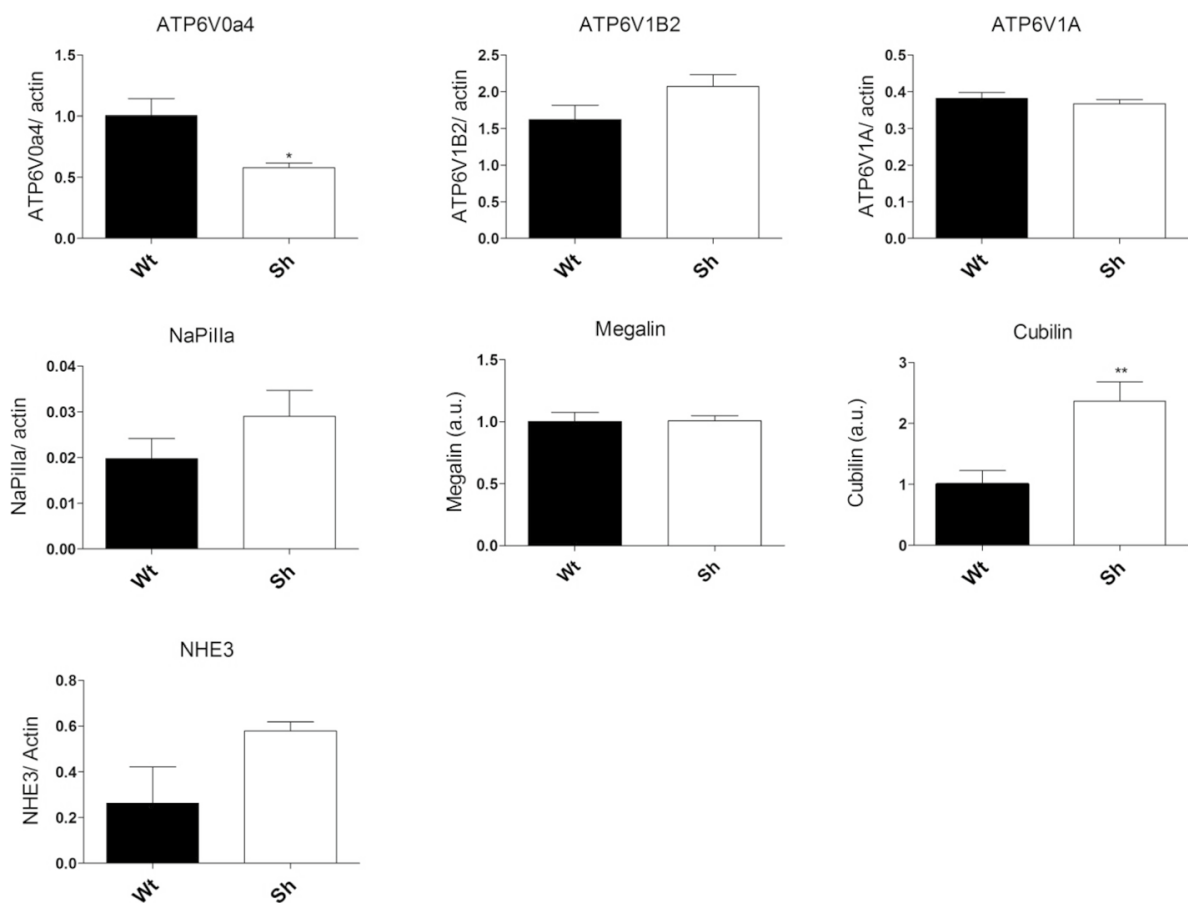

\section{ATP6ap2 deletion in proximal tubule causes a defect in receptor-mediated endocytosis}

Like the rat model, Flox/Pax $8 \mathrm{Cre}+$ mice had albuminuria and low molecular weight proteinuria loosing VDBP and procathepsin B with urine (Fig. 5 and supplementary Fig. 4). In the low doxycycline group, coinjection of the endocytic markers dextran-FITC (10 kDa) and human transferrin confirmed that deletion of the ATP6ap2 affects the receptormediated endocytosis pathway (Fig. 6). Dextran-FITC localization and intensity of staining was similar between animal groups at two time points (10 and $40 \mathrm{~min}$ after injection). Human transferrin staining was similar between genotypes
10 min after injection but showed, like in Sh rats, delayed clearance of transferrin in Flox/Pax $8+$ mice 40 min after injection with perinuclear accumulation (Fig. 6B). Costaining of human transferrin with Lamp1, a lysosomal marker, in kidneys 40 min after injection (Fig. 6C), revealed that in ATP6ap2-deficient animals human transferrin did not overlap with Lamp-1 stained lysosomes suggesting delayed transferrin processing (Fig. 6C). The same reduced colocalization of recombinant human transferrin and Lamp-1 was seen 40 min after injection in mice receiving the higher dose of doxycycline (supplementary Fig. 5).

Western blotting demonstrated reduced expression of the a4 (ATP6V0a4) and EII (ATP6V1EII) $\mathrm{H}^{+}$-ATPase subunits 
Fig. 4 Generation of kidneyepithelial cell-specific ATP6ap2 ablation in mouse. A RT-qPCR analysis of total mRNA of kidneys, lungs, and hearts from $\mathrm{Wt}$ and Flox/Pax $8+$ mice treated with $1 \mathrm{mg} / \mathrm{mL}$ doxycycline (low dose). Atp6ap 2 mRNA abundance was normalized to $H P R T$. Statistical analysis was performed using Student's $t$-test (Wt/Pax $8+: \mathrm{n}=4$ and Flox/ Pax8+: $\mathrm{n}=5$ ) ***p $<0.001$. B Western blotting for ATP6ap2 in total membrane preparations from the kidney of Wt and Flox/ Pax $8+$ mice and summary of data as bar graph. Statistical analysis was performed using Student's $t$-test (Wt/Pax $8+$ : $\mathrm{n}=4$ and Flox/Pax $8+: \mathrm{n}=5$ ) $* \mathrm{p}<0.05$. C Immunohistochemistry for ATP6ap2 (red), AQP2 (green), and DAPI (blue) in kidney sections from $\mathrm{Wt} /$ Pax8 and Flox/Pax 8 + mice with proximal tubules (upper panels) and medullary collecting ducts (lower panels). Scale bar size $100 \mu \mathrm{m}$
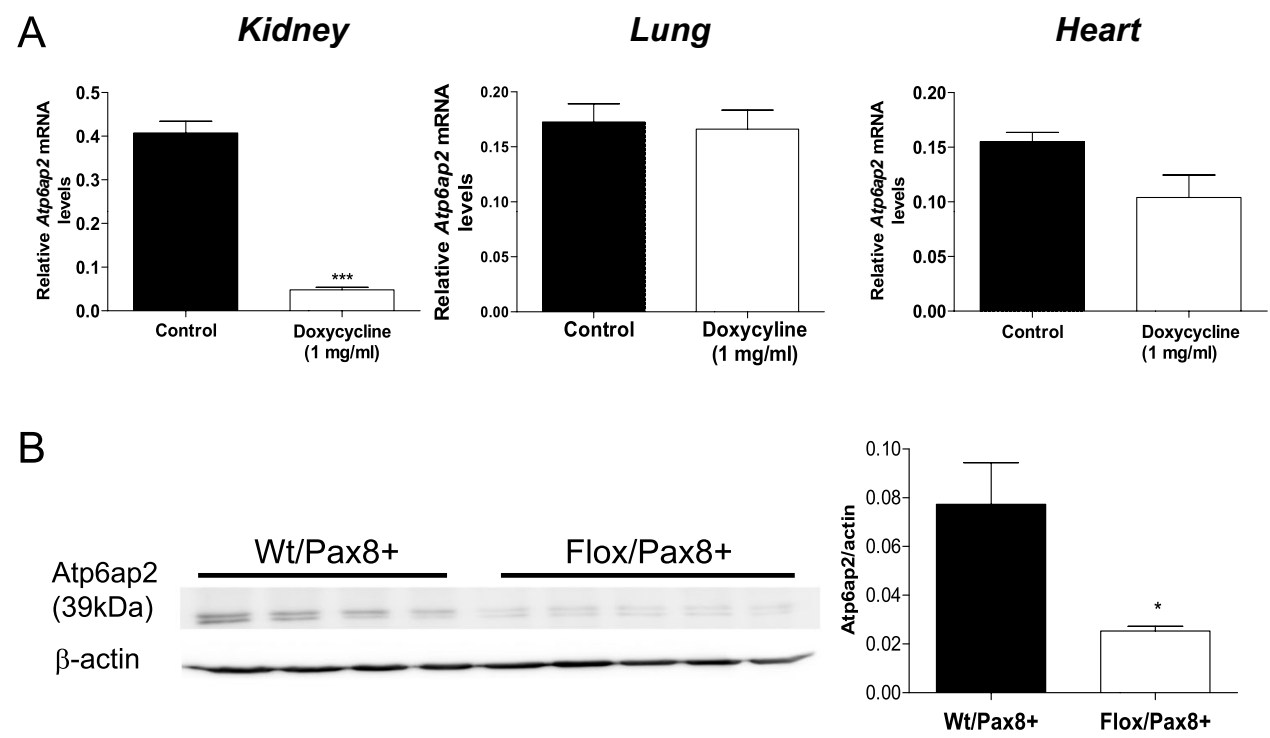

C ATP6ap2 AQP2 DAPI
Flox/ Pax8+
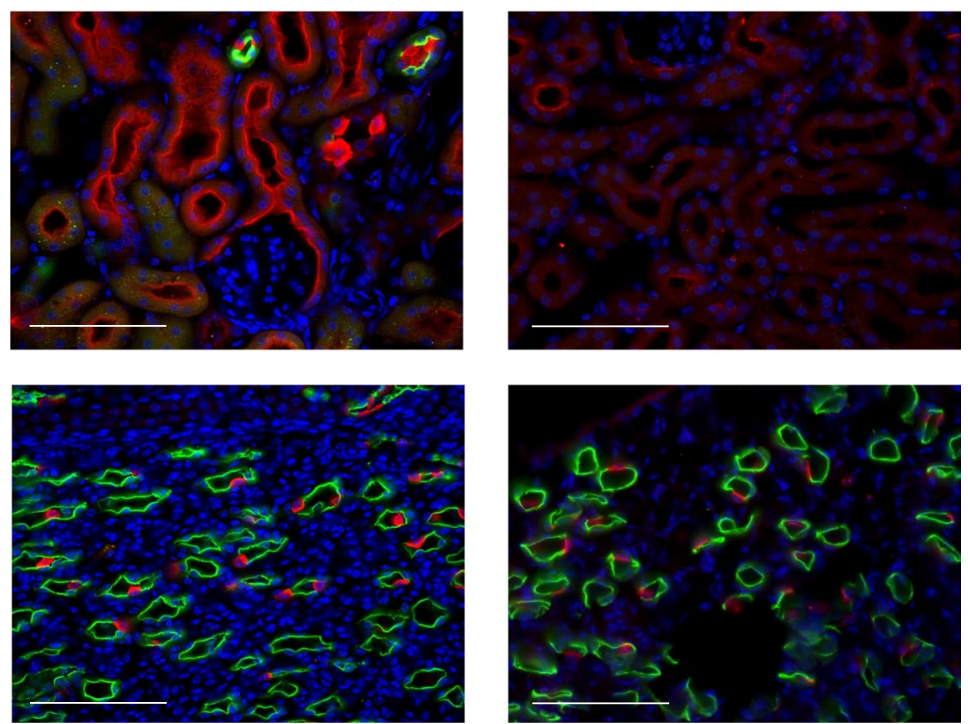

whereas the a2 (ATP6V0a2) and A (ATP6V1A) subunits showed a strong trend to be lowered. ATP6V1B2 protein abundance was unaltered. Megalin, cubilin, and NHE3 abundance was not altered (Fig. 7). Similar results were obtained for the a4 and EII $\mathrm{H}^{+}$-ATPase subunits and megalin in the second group of animals (supplementary Fig. 6).

mTOR signaling is linked to lysosomal function [5, 34, 74]. Vice versa, inhibition of mTOR by rapamycin in mice caused megalin downregulation and proteinuria through a $\mathrm{H}^{+}$-ATPase-dependent mechanism [21]. However, in Flox/ Pax $8+$ kidneys, phosphorylated mTOR and total mTOR amount were unaltered (Fig. 8).
mTOR signaling and ATP6ap2 are linked to autophagy [29, 43, 59]. Immunoblotting and staining for the microtubule-associated protein 1A/1B-light chain 3 or LC3-B, a subunit of the autophagosome showed accumulation of LC3-B in proximal tubules from ATP6ap2 deficient mice but not in wild type controls (Fig. 8B, C).

\section{Discussion}

In this study, we demonstrated that ATP6ap2 plays a role in receptor-mediated endocytosis and lysosomal function in the proximal tubule. Both ATP6ap2-Sh rats and Flox/ 
Table 2 Metabolic and urine parameters of Wt and Flox/Pax $8+$ mice. Animals were induced with the low-dose doxycycline protocol (1 mg/ $\mathrm{mL}$ ). Water and food intake were monitored in metabolic cages under baseline conditions. $24 \mathrm{~h}$ urine and blood were collected for analysis. Statistical analysis was performed using Student's $t$-test ( $\mathrm{n}=8$ in both groups) $* \mathrm{p}<0.05, * * \mathrm{p}<0.01, * * * \mathrm{p}<0.001$

\begin{tabular}{|c|c|c|}
\hline Parameters & $\mathrm{Wt} / \mathrm{Pax} 8+$ & Flox/Pax $8+$ \\
\hline Body weight (g) & $25.2 \pm 1.0$ & $23.6 \pm 1.8 *$ \\
\hline $\mathrm{H}_{2} \mathrm{O}$ intake $(\mathrm{g} / \mathrm{g} \mathrm{BW})$ & $0.19 \pm 0.02$ & $0.26 \pm 0.01 *$ \\
\hline Food intake (g/g BW) & $0.16 \pm 0.02$ & $0.19 \pm 0.01$ \\
\hline \multicolumn{3}{|l|}{ Plasma } \\
\hline $\mathrm{pH}$ & $7.26 \pm 0.03$ & $7.27 \pm 0.05$ \\
\hline Glucose (mg/dL) & $250.5 \pm 8.9$ & $238.9 \pm 15.3$ \\
\hline $\mathrm{Na}^{+}(\mathrm{mM})$ & $144.7 \pm 1.1$ & $146.0 \pm 1.1$ \\
\hline $\mathrm{K}^{+}(\mathrm{mM})$ & $3.9 \pm 0.4$ & $3.2 \pm 0.1 *$ \\
\hline Ionized $\mathrm{Ca}^{2+}(\mathrm{mM})$ & $0.96 \pm 0.23$ & $1.11 \pm 0.05$ \\
\hline $\mathrm{Cl}^{-}(\mathrm{mM})$ & $108.2 \pm 1.5$ & $109.2 \pm 0.1$ \\
\hline Phosphate (mg/dL) & $5.9 \pm 0.1$ & $6.2 \pm 0.3$ \\
\hline Prealbumin (mg/dL) & $1.76 \pm 0.42$ & $1.88 \pm 0.15$ \\
\hline Creatinine (mg/dL) & $0.05 \pm 0.01$ & $0.07 \pm 0.01$ \\
\hline BUN (mg/dL) & $40.6 \pm 5.9$ & $40.7 \pm 3.3$ \\
\hline \multicolumn{3}{|l|}{ Urine } \\
\hline Urine (g/g BW) & $0.051 \pm 0.009$ & $0.083 \pm 0.008 *$ \\
\hline Creatinine (mg/dL) & $63.0 \pm 4.2$ & $42.8 \pm 2.9 * *$ \\
\hline Creatinine clearance $(\mu \mathrm{L} / \mathrm{min})$ & $109 \pm 35$ & $98 \pm 23$ \\
\hline $\mathrm{Na}^{+}(\mathrm{mM}) / \mathrm{Crea}(\mathrm{mg} / \mathrm{dL})$ & $1.7 \pm 0.2$ & $5.8 \pm 1.1 * *$ \\
\hline $\mathrm{K}^{+}(\mathrm{mM}) / \mathrm{Crea}(\mathrm{mg} / \mathrm{dL})$ & $6.0 \pm 0.3$ & $7.1 \pm 0.3^{*}$ \\
\hline $\mathrm{Ca}^{2+}(\mathrm{mM}) / \mathrm{Crea}(\mathrm{mg} / \mathrm{dL})$ & $0.03 \pm 0.01$ & $0.01 \pm 0.21 *$ \\
\hline $\mathrm{Mg}^{2+}(\mathrm{mg} / \mathrm{dL}) / \mathrm{Crea}(\mathrm{mg} / \mathrm{dL})$ & $1.65 \pm 0.10$ & $1.70 \pm 6.25$ \\
\hline Phosphate (mg/dL)/Crea (mg/dL) & $6.7 \pm 0.4$ & $7.1 \pm 0.6$ \\
\hline $\mathrm{Cl}^{-}(\mathrm{mM}) / \mathrm{Crea}(\mathrm{mg} / \mathrm{dL})$ & $4.0 \pm 0.2$ & $5.0 \pm 0.3$ \\
\hline
\end{tabular}

Pax 8 Cre + mice showed excretion of albumin and low molecular weight proteins in urine, delayed processing of substrates of the receptor-mediated endocytosis pathway, and reduced expression of other key molecules involved in this process as well as accumulation of the LC3-B subunit of the autophagosome. All these changes are consistent with impaired lysosome function and reduced activity of the receptor-mediated endocytosis pathway.

We used two rodent models to demonstrate a role of ATP6ap2 in proximal tubule endocytosis of low molecular weight proteins and lysosomal function. Both models yield similar results as discussed below in more detail. The mouse model used is similar to previously published models with a more severe renal defect including an urinary concentration defect, salt loss, and distal renal tubular acidosis [56, 57, 70]. However, there are major differences between these models and our model. We induced Pax8-driven Cre activity in animals $6-8$ weeks old whereas in the published models doxycycline was given already to mothers or to animals after weaning. Moreover, we used in the first model a lower doxycycline dose [44] to induce Cre activity and deletion of ATP6ap2 as we had previously observed that higher doses resulted also in a transient renal phenotype in animals not expressing any transgene. The low-dose doxycycline protocol resulted in an almost complete deletion of ATP6ap2 in the proximal tubule but with well-preserved expression in the collecting duct thereby circumventing a more severe renal damage and phenotype allowing to focus on proximal tubule functions. Likewise, the higher dose of doxycycline deleted ATPap2 from the proximal tubule but maintained most of the intercalated cell expression as evident from immunohistochemistry and normal urine $\mathrm{pH}$. Consequently, our model did not develop signs of renal acidosis. This is important to consider as metabolic acidosis has recently been shown to impair proximal tubule endocytosis [11] and the defect described here is likely not caused by systemic alterations in acid-base balance.

ATP6ap2 associates with $\mathrm{H}^{+}$-ATPases $[15,36,41$, $52,61]$. We and others had shown that the ATP6ap2 is expressed in the renal proximal tubule and colocalizes with $\mathrm{H}^{+}$-ATPases in this nephron segments $[17,28,60]$. $\mathrm{H}^{+}$-ATPases contribute to several functions of the proximal tubule such as reabsorption of bicarbonate, trafficking and recycling of membrane proteins, or endocytosis of proteins from urine, acidification of vesicles along the endocytic pathway, and lysosomes processing or degrading absorbed substrates [71].

Several lines of evidence suggest that the ATP6ap2 modulates $\mathrm{H}^{+}$-ATPase function in the proximal tubule and thereby contributes to receptor-mediated endocytosis and lysosomal function. However, our data do not support a role of the ATP6ap2 in fluid-phase mediated endocytosis as suggested by data from Drosophila [25] or other generalized functions of the proximal tubule. Urine analysis and immunoblotting showed no generalized Fanconi-syndrome like loss of function as indicated by the absence of glucosuria, massive proteinuria, or changes in urine and blood $\mathrm{pH}$. Both, Sh rats with reduced ATP6ap2 and ATP6ap2 KO mice, showed albuminuria in combination with the presence of low molecular weight proteins such as the vitamin D binding protein (VDBP) or procathepsin B. Also, injected recombinant transferrin was found in urine of Sh rats. Thus, these findings are indicative of reduced proximal tubular protein absorption. In the case of the Sh rats, we cannot exclude also increased filtration of albumin or transferrin as in these animals ATP6ap2 expression in podocytes may be reduced and podocyte-specific deletion of ATP6ap2 causes massive proteinuria and glomerular damage $[49,59]$. Therefore, we created a mouse model with deletion of the ATP6ap2 in 
Fig. 5 Albuminuria and low molecular weight proteinuria in the absence of the ATP6ap2. Urine samples were normalized to creatinine. Bovine serum albumin (BSA, $7 \mathrm{mg}$ / $\mathrm{mL}$ ) was loaded as positive control. A Albumin was detected by Coomassie blue staining whereas $\mathbf{B}$ vitamin D binding protein (VDBP) or $\mathbf{C}$ (Pro)cathepsin B was revealed by immunoblotting. Data were summarized as bar graphs $(\mathrm{n}=4 /$ genotype. Student's $t$-test $* \mathrm{p}<0.05, * * * \mathrm{p}<0.001$

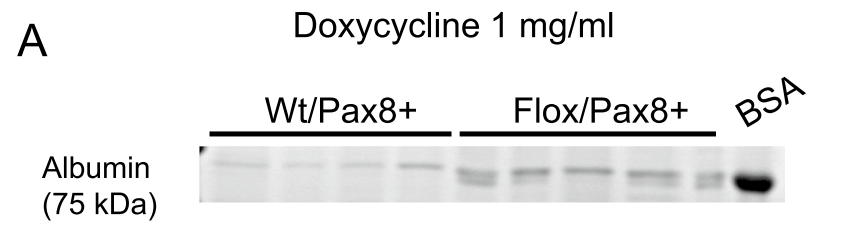

B
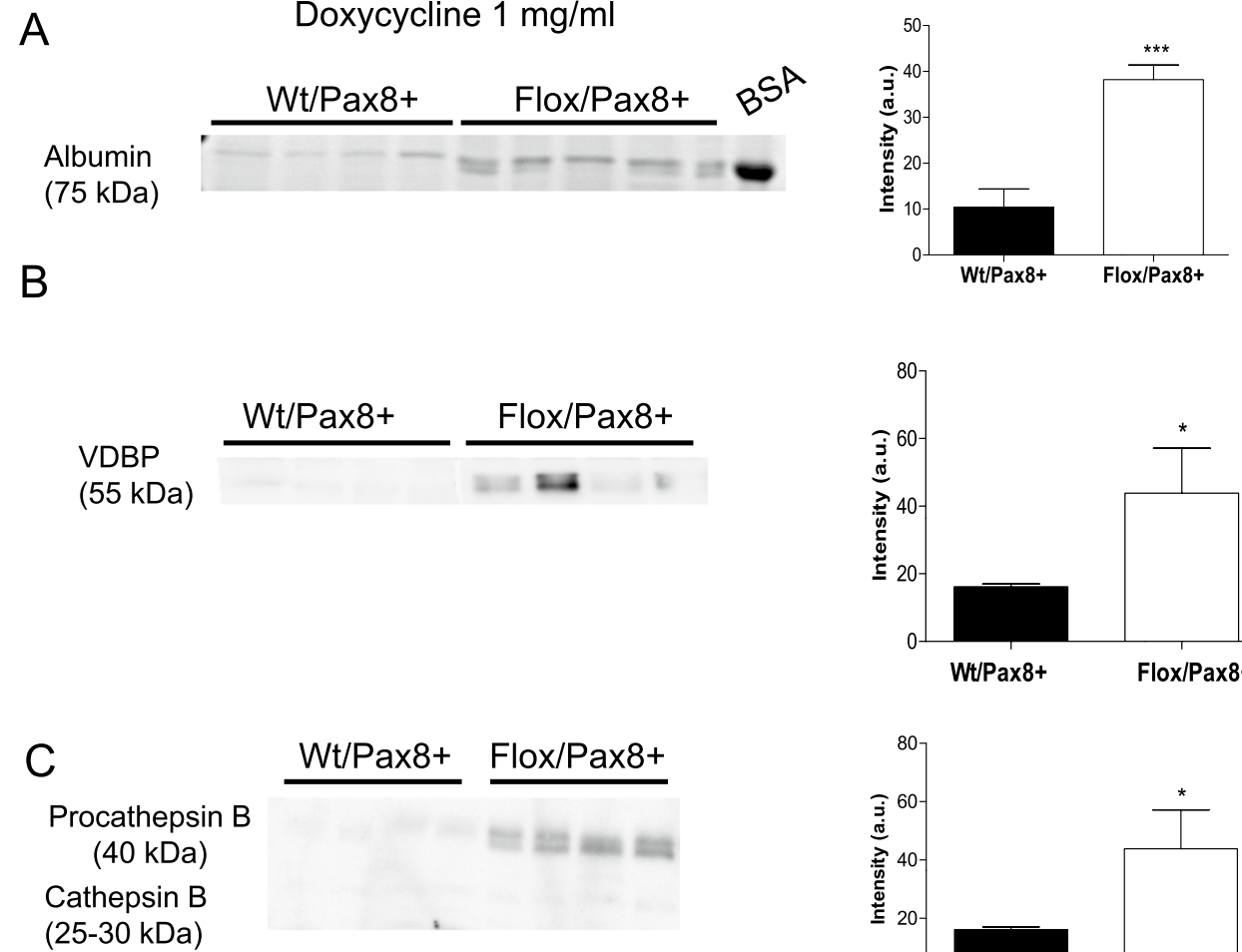
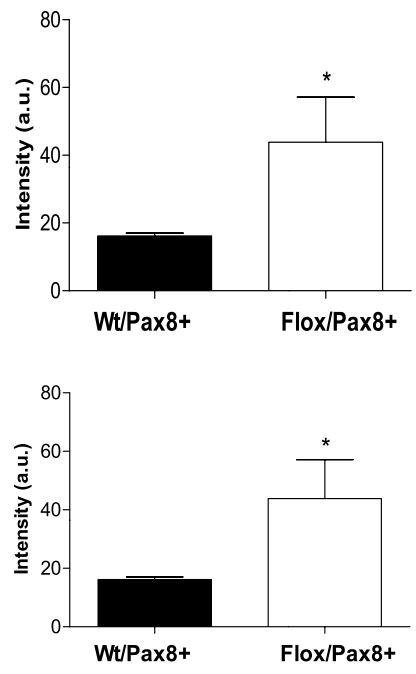

the epithelial cells along the nephron with intact expression of the protein in podocytes and found similar urinary excretion of albumin, VDBP, and procathepsin. Absorption of these proteins depends on the initial recognition by and binding to the multi-specific receptors megalin and cubilin present in the brush border membrane [47]. Deletion of the ATP6ap2 did not alter overall abundance of these receptors and also did not affect their localization at the level of light microscopy. Proteins bound to these receptors are then internalized in a receptor-ligand complex and further processed through early endosomes to late endosomes and lysosomes. In our experiments, four different ligands of these receptors were further investigated: albumin and VDBP which are internalized by both megalin and cubilin, procathepsin B which is preferentially absorbed by megalin, and transferrin a preferred substrate for cubilin [47]. All four proteins were found at elevated levels in urine suggesting a defect common to both receptors. The number of urine samples available for analysis was low precluding a more detailed analysis and more robust statistics. Nevertheless, more detailed analysis of transferrin internalization showed that transferrin is taken up from urine, albeit at somewhat lower rates (as indicated by higher urinary excretion after injection of transferrin) and that processing of transferrin to lysosomes is delayed as suggested by accumulation of transferrin 40 min after injection and much reduced colocalization of injected transferrin with a lysosomal marker (Lamp-1) at this later time point.

The delayed processing of endocytic substrates is most likely due to a reduced capacity of endocytic and lysosomal vesicles to acidify. A role of the ATP6ap2 in endosomal acidification has been described in Xenopus frog embryos and linked to reduced $\mathrm{H}^{+}$-ATPase activity [15]. Consistently, we found decreased expression of several $\mathrm{H}^{+}$-ATPase subunits including the a4 subunit (ATP6V0a4) in Sh rats and KO mice as well as the EII (ATP6V1EII) subunit in the KO mice. Similarly, ablation of the ATP6ap2 in embryonic cardiomyocytes reduced expression of several subunits of the $\mathrm{V}_{0}$ domain of the $\mathrm{H}^{+}$-ATPase and impaired lysosomal acidification [30]. In mice, deletion of ATP6V0a4 causes proximal tubular dysfunction and reduced receptor-mediated endocytosis with impaired lysosomal function consistent with an important role of $\mathrm{H}^{+}$-ATPases in these processes [22]. Whether the lower expression of the a4 subunit in the ATP6ap2 deficient rodent models is the consequence of absent ATP6ap2 function and/or directly causes the endocytic and lysosomal defect remains unclear at this point. 
Fig. 6 Delayed receptor-mediated endocytosis in ATP6ap2 deleted mice. WT/Pax $8+$ and Flox/Pax $8+$ mice were coinjected with dextran-FITC $(10 \mathrm{kDa})$ and human recombinant transferrin. Kidneys were collected 10 and 40 min after injection. A Immunohistochemistry for dextran-FITC, $10 \mathrm{kDa}$ (green), DAPI (blue), and actin/ phalloidin (red) in kidney slices from Wt and Flox/Pax8 + mice 10 and 40 min after injection. B Immunohistochemistry for human transferrin (red), DAPI (blue), and megalin (green) in kidneys from Wt and Flox/ Pax $8+$ mice 10 and 40 min after injection. C Immunohistochemistry for Lamp-1 (green) and human transferrin (red) $40 \mathrm{~min}$ after injection. Scale bar size $50 \mu \mathrm{m}$ for all pictures

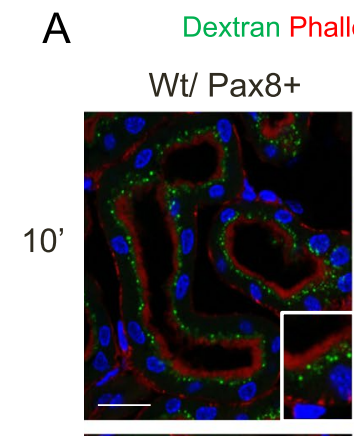

idin DAPI

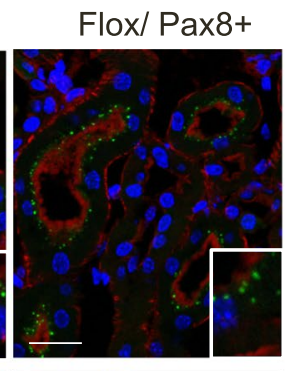

B

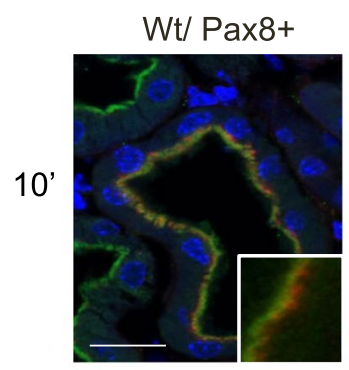

Megalin Transferrin DAPI
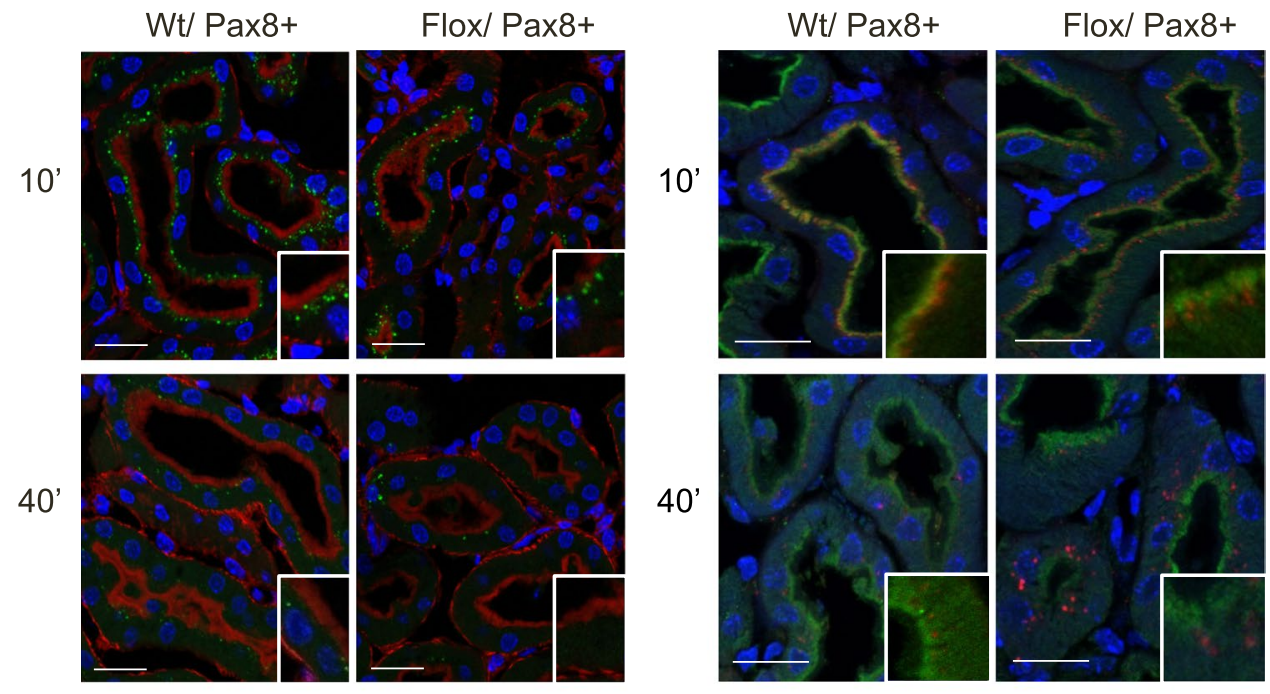

C

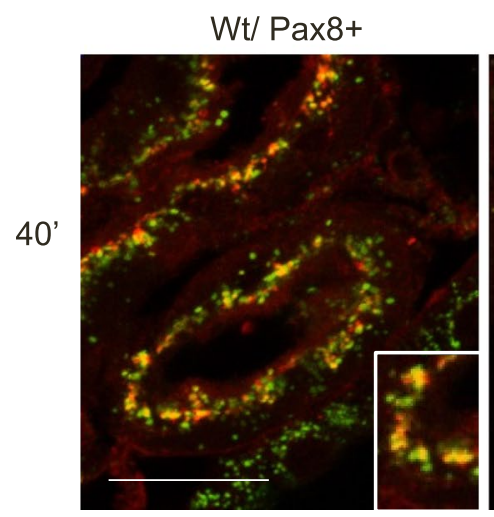

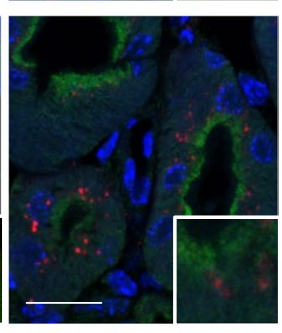
Lamp-1 Transferrin

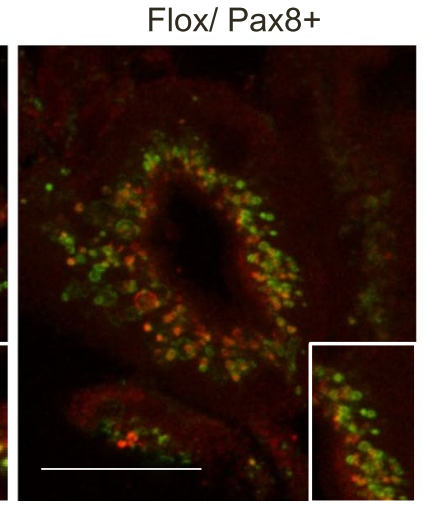

Defects in lysosomal acidification due to reduced or absent $\mathrm{H}^{+}$-ATPase function can cause altered mTOR signaling and activation of the autophagosome as in X-linked autophagic myopathy due to mutations in the VMA21 protein required for lysosomal $\mathrm{H}^{+}$-ATPase assembly [55] or in podocytes with specific deletion of the ATP6ap2 and impaired lysosomal function [49, 59]. Also in liver cells or pancreatic beta cells, absence or mutation of ATP6ap2 causes a lysosomal defect with impaired autophagy and vacuolation [7, 12, 62]. Fusion of lysosomes and autophagosomes occurs independently from lysosomal acidification but requires $\mathrm{H}^{+}$-ATPases [38]. Lysosomes act as signaling platforms associating with the mTOR complex 1 and $\mathrm{H}^{+}$-ATPase function is required for mTORC1 signaling whereas in turn mTOR signaling regulates $\mathrm{H}^{+}$-ATPase expression $[50,75]$. mTOR is also a regulator of autophagosome function and autophagosome-lysosomal fusion and reduced mTOR signaling impairs autophagosome-lysosome fusion [27, 39]. Thus, deletion of the ATP6ap2 may impair $\mathrm{H}^{+}$-ATPase assembly and function, thereby decreasing endosomal and lysosomal acidification as well as mTOR signaling. Consequently, lysosome-autophagosome fusion may be decreased due to $\mathrm{H}^{+}$-ATPase-dependent but acidificationindependent as well as mTOR-dependent mechanisms. Of note, increased levels of the ATP6ap2 in a podocyte cell line enhance mTOR signaling and reduce autophagosome expression and activity [35]. We found in the ATPap2 KO mouse models increased accumulation of the LC3B autophagosome subunit in proximal tubule cells whereas mTOR signaling appeared not to be affected.

In the rat model, Sh rats showed altered tubular morphology in H\&E stained sections with vacuoles prominently present in proximal tubules. While the cause of these vacuoles remains elusive, the vacuoles potentially 
Fig. 7 Deletion of the ATP6ap2 alters expression of major proteins in the endocytic pathway. A Brush border membrane preparations from kidneys of Wt/Pax $8+$ and Flox/ Pax $8+$ mice were blotted for the $\mathrm{H}^{+}$ATPase a4 (ATP6V0a4), a2 (ATP6V0a2), EII (ATP6V1EII), B2 (ATP6V1B2), and A (ATP6V1A) subunits as well as for NHE3, megalin, and cubilin. B Densitometries were normalized to $\beta$-actin (loading control). Student's $t$-test $(\mathrm{n}=4$ per group), $* * \mathrm{p} \leq 0.01$, $* * * \mathrm{p} \leq 0.001$

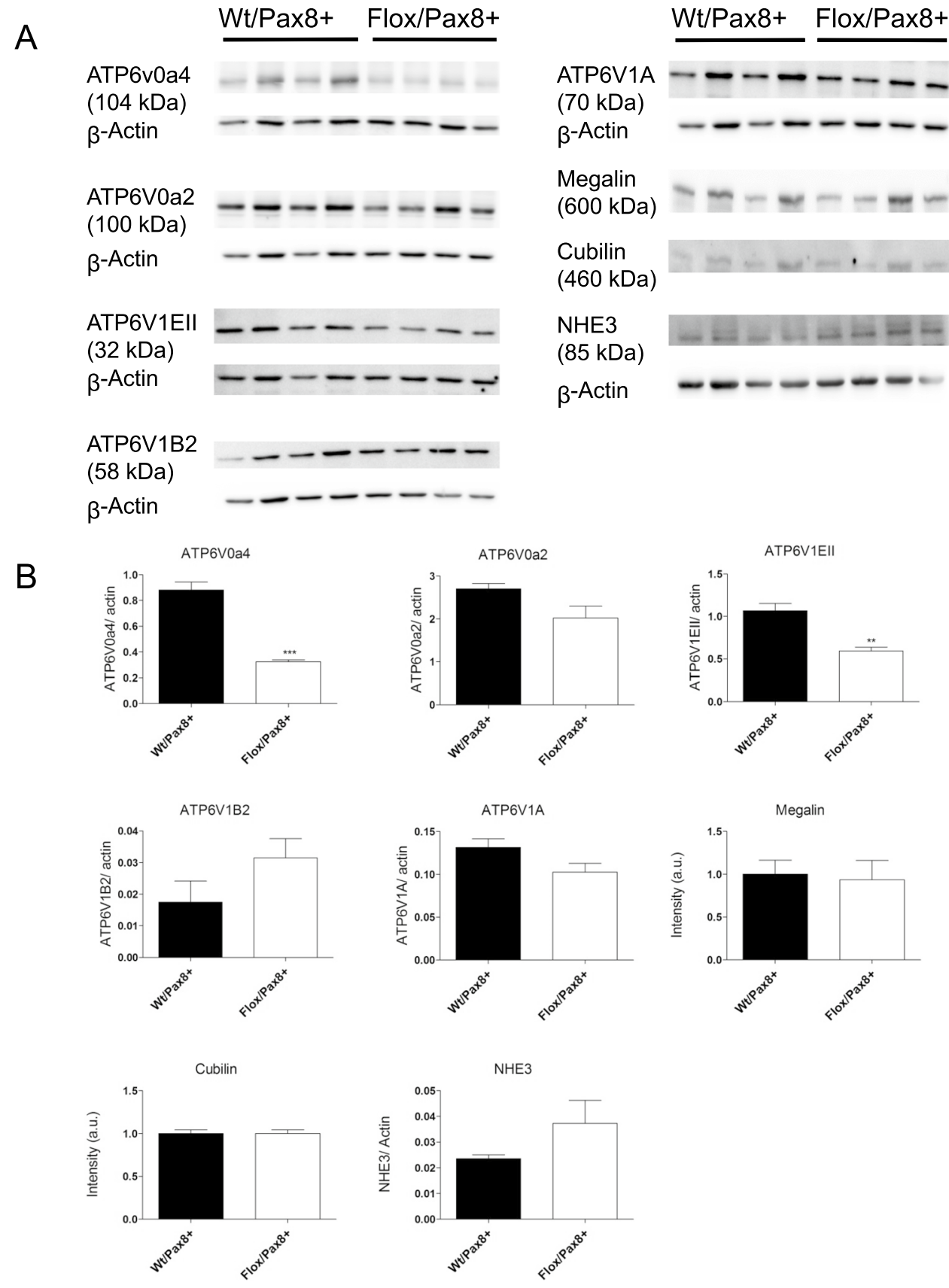

impair overall proximal tubule function and may particularly impact on endocytosis and vesicular trafficking contributing to the observed defect in endocytosis. However, the fact that a similar defect in endocytosis was also observed in the mouse models with apparently normal proximal tubular morphology (at least by light microscopy) strongly suggests that the loss of ATP6ap 2 through mechanisms discussed above impairs endocytosis and processing of cargo.
In summary, genetic deletion of the (P)RR/ATP6ap2 from the proximal tubule in rats and mice causes albuminuria and low molecular weight proteinuria paralleled by reduced expression of several $\mathrm{H}^{+}$-ATPase subunits and delayed processing of substrates of receptor-mediated endocytosis to lysosomes. Lysosomal dysfunction is suggested by accumulation of the LC3-B subunit of the autophagosome. Thus, the ATPap2 facilitates receptor-mediated endocytosis in the proximal tubule possibly by modulating $\mathrm{H}^{+}$-ATPases. 
Fig. 8 Accumulation of autophagosomes in ATP6ap2 deficient mice. A, B Western blotting for total and phosphorylated mammalian target of rapamycin (mTOR) and the LC3B subunit of the autophagosome and densitometry summarizing results. Student's $t$-test ( $\mathrm{n}=4$ per group), $* * \mathrm{p} \leq 0.01$.

C Immunohistochemistry for microtubule-associated proteins 1A/1B light chain 3B (LC3B) (red) and DAPI (blue) in kidneys from Wt and Flox/ Pax $8+$ mice insert shows higher magnification. Scale size bar $100 \mu \mathrm{m}$
A
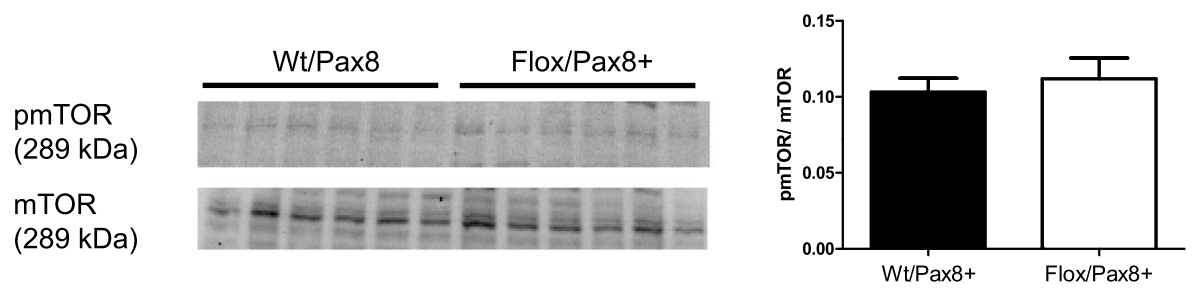

B

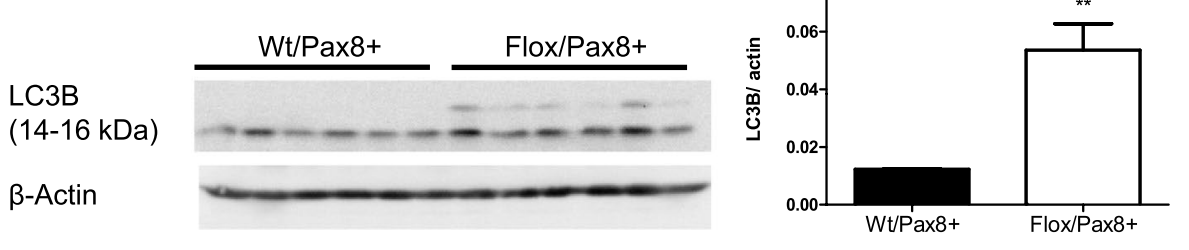

C

Wt/ Pax8+

Flox/ Pax8+

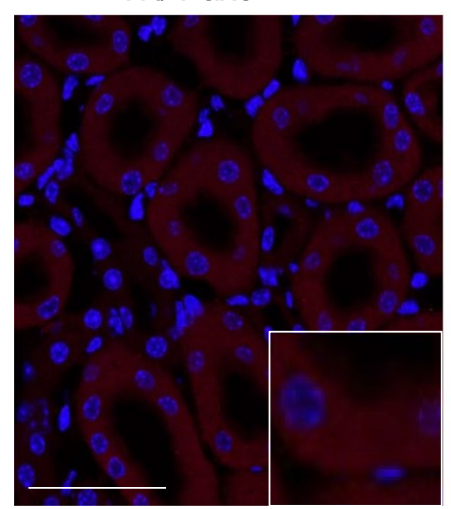

Supplementary Information The online version contains supplementary material available at https://doi.org/10.1007/s00424-021-02598-z.

Acknowledgements Dr. J. Loffing, University of Zurich, kindly provided rabbit anti-AQP2 antibodies. Dr. X.S. Xie, University of Texas, Dallas, TX, and Dr. E. I. Christensen, University of Aarhus, kindly provided antibodies against ATP6V0a2, megalin, and cubilin, respectively.

Funding Open Access funding provided by Universität Zürich. This study was financially supported by grants from the Swiss National Science Foundation (31003A_138143 and 31003A_155959) to C. A. Wagner. M. Bader and D.N. Müller were supported by a grant of the German Research Foundation (DFG, SFB1365).

Open Access This article is licensed under a Creative Commons Attribution 4.0 International License, which permits use, sharing, adaptation, distribution and reproduction in any medium or format, as long as you give appropriate credit to the original author(s) and the source, provide a link to the Creative Commons licence, and indicate if changes were made. The images or other third party material in this article are included in the article's Creative Commons licence, unless indicated otherwise in a credit line to the material. If material is not included in the article's Creative Commons licence and your intended use is not permitted by statutory regulation or exceeds the permitted use, you will need to obtain permission directly from the copyright holder. To view a copy of this licence, visit http://creativecommons.org/licenses/by/4.0/.

\section{References}

1. Advani A, Kelly DJ, Cox AJ, White KE, Advani SL, Thai K, Connelly KA, Yuen D, Trogadis J, Herzenberg AM, Kuliszewski MA, Leong-Poi H, Gilbert RE (2009) The (Pro)renin receptor: site-specific and functional linkage to the vacuolar H+-ATPase in the kidney. Hypertension 54:261-269. https://doi.org/10.1161/ HYPERTENSIONAHA.109.128645

2. Bachmann S, Schlichting U, Geist B, Mutig K, Petsch T, Bacic D, Wagner CA, Kaissling B, Biber J, Murer H, Willnow TE (2004) Kidney-specific inactivation of the megalin gene impairs 
trafficking of renal inorganic sodium phosphate cotransporter (NaPi-IIa). J Am Soc Nephrol 15:892-900

3. Bacic D, Capuano P, Gisler SM, Pribanic S, Christensen EI, Biber J, Loffing J, Kaissling B, Wagner CA, Murer H (2003) Impaired PTH-induced endocytotic down-regulation of the renal type IIa $\mathrm{Na}^{+} / \mathrm{P}_{\mathrm{i}}$-cotransporter in RAP deficient mice with reduced megalin expression. Pflügers Arch 446:475-484

4. Bastani B, Purcell H, Hemken P, Trigg D, Gluck S (1991) Expression and distribution of renal vacuolar proton-translocating adenosine triphosphatase in response to chronic acid and alkali loads in the rat. J Clin Invest 88:126-136

5. Betz C, Hall MN (2013) Where is mTOR and what is it doing there? J Cell Biol 203:563-574. https://doi.org/10.1083/jcb. 201306041

6. Biber J, Stieger B, Stange G, Murer H (2007) Isolation of renal proximal tubular brush-border membranes. Nat Protoc 2:13561359. https://doi.org/10.1038/nprot.2007.156

7. Binger KJ, Neukam M, Tattikota SG, Qadri F, Puchkov D, Willmes DM, Wurmsee S, Geisberger S, Dechend R, Raile K, Kurth T, Nguyen G, Poy MN, Solimena M, Muller DN, Birkenfeld AL (2019) Atp6ap2 deletion causes extensive vacuolation that consumes the insulin content of pancreatic beta cells. Proc Natl Acad Sci U S A 116:19983-19988. https://doi.org/10.1073/ pnas. 1903678116

8. Breton S, Brown D (2013) Regulation of luminal acidification by the V-ATPase. Physiology (Bethesda) 28:318-329. https:// doi.org/10.1152/physiol.00007.2013

9. Buechling T, Bartscherer K, Ohkawara B, Chaudhary V, Spirohn K, Niehrs C, Boutros M (2010) Wnt/Frizzled signaling requires dPRR, the Drosophila homolog of the prorenin receptor. Curr Biol 20:1263-1268. https://doi.org/10.1016/j.cub.2010.05.028

10. Buechling T, Bartscherer K, Ohkawara B, Chaudhary V, Spirohn K, Niehrs C, Boutros M (2010) Wnt/Frizzled signaling requires dPRR, the Drosophila homolog of the prorenin receptor. Curr Biol : CB 20:1263-1268. https://doi.org/10.1016/j.cub.2010.05. 028

11. Bugarski M, Ghazi S, Polesel M, Martins JR, Hall AM (2021) Changes in NAD and lipid metabolism drive acidosis-induced acute kidney injury. J Am Soc Nephrol. https://doi.org/10.1681/ ASN.2020071003

12. Cannata Serio M, Rujano MA, Simons M (2018) Mutations in ATP6AP2 cause autophagic liver disease in humans. Autophagy 14:1088-1089. https://doi.org/10.1080/15548627.2018.1434370

13. Christensen EI, Birn H (2002) Megalin and cubilin: multifunctional endocytic receptors. Nat Rev Mol Cell Biol 3:256-266. https://doi.org/10.1038/nrm778nrm778[pii]

14. Christensen EI, Devuyst O, Dom G, Nielsen R, Van Der Smissen P, Verroust P, Leruth M, Guggino WB, Courtoy PJ (2003) Loss of chloride channel ClC-5 impairs endocytosis by defective trafficking of megalin and cubilin in kidney proximal tubules. Proc Natl Acad Sci U S A 100:8472-8477

15. Cruciat CM, Ohkawara B, Acebron SP, Karaulanov E, Reinhard C, Ingelfinger D, Boutros M, Niehrs C (2010) Requirement of prorenin receptor and vacuolar H+-ATPase-mediated acidification for Wnt signaling. Science 327:459-463. https://doi.org/10. 1126/science. 1179802

16. Custer M, Lötscher M, Biber J, Murer H, Kaissling B (1994) Expression of $\mathrm{Na}-\mathrm{P}_{\mathrm{i}}$ cotransport in rat kidney: localization by RT-PCR and immunohistochemistry. Am J Physiol 266:F767-774

17. Daryadel A, Bourgeois S, Figueiredo MF, Gomes Moreira A, Kampik NB, Oberli L, Mohebbi N, Lu X, Meima ME, Danser AH, Wagner CA (2016) Colocalization of the (pro)renin receptor/Atp6ap2 with $\mathrm{H}+$-aTPases in mouse kidney but prorenin does not acutely regulate intercalated cell $\mathrm{H}+$-ATPase activity.
PLoS One 11:e0147831. https://doi.org/10.1371/journal.pone. 0147831

18. de Seigneux S, Courbebaisse M, Rutkowski JM, Wilhelm-Bals A, Metzger M, Khodo SN, Hasler U, Chehade H, Dizin E, Daryadel A, Stengel B, Girardin E, Prie D, Wagner CA, Scherer PE, Martin PY, Houillier P, Feraille E (2015) Proteinuria increases plasma phosphate by altering its tubular handling. J Am Soc Nephrol 26:1608-1618. https://doi.org/10.1681/ASN.20140 10104

19. Forgac M (2007) Vacuolar ATPases: rotary proton pumps in physiology and pathophysiology. Nat Rev Mol Cell Biol 8:917-929. https://doi.org/10.1038/nrm2272

20. Frattini A, Orchard PJ, Sobacchi C, Giliani S, Abinun M, Mattsson JP, Keeling DJ, Andersson AK, Wallbrandt P, Zecca L, Notarangelo LD, Vezzoni P, Villa A (2000) Defects in TCIRG1 subunit of the vacuolar proton pump are responsible for a subset of human autosomal recessive osteopetrosis. Nat Genet 25:343-346

21. Gleixner EM, Canaud G, Hermle T, Guida MC, Kretz O, Helmstadter M, Huber TB, Eimer S, Terzi F, Simons M (2014) V-ATPase/mTOR signaling regulates megalin-mediated apical endocytosis. Cell Rep 8:10-19. https://doi.org/10.1016/j.celrep. 2014.05.035

22. Hennings JC, Picard N, Huebner AK, Stauber T, Maier H, Brown D, Jentsch TJ, Vargas-Poussou R, Eladari D, Hubner CA (2012) A mouse model for distal renal tubular acidosis reveals a previously unrecognized role of the V-ATPase a4 subunit in the proximal tubule. EMBO Mol Med 4:1057-1071. https://doi.org/10.1002/ emmm. 201201527

23. Hermle T, Guida MC, Beck S, Helmstadter S, Simons M (2013) Drosophila ATP6AP2/VhaPRR functions both as a novel planar cell polarity core protein and a regulator of endosomal trafficking. EMBO J 32:245-259. https://doi.org/10.1038/emboj.2012.323

24. Hermle T, Guida MC, Beck S, Helmstädter S, Simons M (2013) Drosophila ATP6AP2/VhaPRR functions both as a novel p. EMBO J 32:245-259. https://doi.org/10.1038/emboj.2012.323

25. Hermle T, Saltukoglu D, Grunewald J, Walz G, Simons M (2010) Regulation of Frizzled-dependent planar polarity signaling by a V-ATPase subunit. Curr Biol 20:1269-1276. https://doi.org/10. 1016/j.cub.2010.05.057

26. Hermle T, Saltukoglu D, Grünewald J, Walz G, Simons M (2010) Regulation of Frizzled-dependent planar polarity signaling by a V-ATPase subunit. Curr Biol 20:1269-1276. https://doi.org/10. 1016/j.cub.2010.05.057

27. Hosokawa N, Hara T, Kaizuka T, Kishi C, Takamura A, Miura Y, Iemura S, Natsume T, Takehana K, Yamada N, Guan JL, Oshiro $\mathrm{N}$, Mizushima N (2009) Nutrient-dependent mTORC1 association with the ULK1-Atg13-FIP200 complex required for autophagy. Mol Biol Cell 20:1981-1991. https://doi.org/10.1091/mbc. E08-12-1248

28. Huang J, Ledford KJ, Pitkin WB, Russo L, Najjar SM, Siragy HM (2013) Targeted deletion of murine CEACAM 1 activates PI3K-Akt signaling and contributes to the expression of (Pro)renin receptor via CREB family and NF-kappaB transcription factors. Hypertension 62:317-323. https://doi.org/10.1161/HYPERTENSI ONAHA.113.01324

29. Kim YC, Guan KL (2015) mTOR: a pharmacologic target for autophagy regulation. J Clin Invest 125:25-32. https://doi.org/ 10.1172/JCI73939

30. Kinouchi K, Ichihara A, Sano M, Sun-Wada GH, Wada Y, Kurauchi-Mito A, Bokuda K, Narita T, Oshima Y, Sakoda M, Tamai Y, Sato H, Fukuda K, Itoh H (2010) The (pro)renin receptor/ATP6AP2 is essential for vacuolar $\mathrm{H}+$-ATPase assembly in murine cardiomyocytes. Circ Res 107:30-34. https://doi. org/10.1161/CIRCRESAHA.110.224667

31. Kinouchi K, Ichihara A, Sano M, Sun-Wada GH, Wada Y, Ochi H, Fukuda T, Bokuda K, Kurosawa H, Yoshida N, Takeda S, 
Fukuda K, Itoh H (2013) The role of individual domains and the significance of shedding of ATP6AP2/(pro)renin receptor in vacuolar $\mathrm{H}(+)$-ATPase biogenesis. PLoS One 8:e78603. https:// doi.org/10.1371/journal.pone.0078603

32. Kotnik K, Popova E, Todiras M, Mori MA, Alenina N, Seibler J, Bader M (2009) Inducible transgenic rat model for diabetes mellitus based on shRNA-mediated gene knockdown. PLoS One 4:e5124. https://doi.org/10.1371/journal. pone.0005124

33. Krop M, Lu X, Danser AH, Meima ME (2013) The (pro)renin receptor. A decade of research: what have we learned? Pflugers Arch 465:87-97. https://doi.org/10.1007/s00424-012-1105-Z

34. Laplante M, Sabatini DM (2012) mTOR signaling in growth control and disease. Cell 149:274-293. https://doi.org/10. 1016/j.cell.2012.03.017

35. Li C, Siragy HM (2015) (Pro)renin receptor regulates autophagy and apoptosis in podocytes exposed to high glucose. Am J Physiol Endocrinol Metab 309:E302-E310. https://doi.org/10.1152/ ajpendo.00603.2014

36. Ludwig J, Kerscher S, Brandt U, Pfeiffer K, Getlawi F, Apps DK, Schagger H (1998) Identification and characterization of a novel 9.2-kDa membrane sector-associated protein of vacuolar proton-ATPase from chromaffin granules. J Biol Chem 273:10939-10947

37. Marshansky V, Ausiello DA, Brown D (2002) Physiological importance of endosomal acidification: potential role in proximal tubulopathies. Curr Opin Nephrol Hypertens 11:527-537

38. Mauvezin C, Nagy P, Juhasz G, Neufeld TP (2015) Autophagosome-lysosome fusion is independent of V-ATPase-mediated acidification. Nat Commun 6:7007. https://doi.org/10.1038/ncomm s8007

39. Mavrakis M, Lippincott-Schwartz J, Stratakis CA, Bossis I (2006) Depletion of type IA regulatory subunit (RIalpha) of protein kinase A (PKA) in mammalian cells and tissues activates mTOR and causes autophagic deficiency. Hum Mol Genet 15:2962-2971. https://doi.org/10.1093/hmg/dd1239

40. Maxson ME, Grinstein S (2014) The vacuolar-type H(+)-ATPase at a glance - more than a proton pump. J Cell Sci 127:4987-4993. https://doi.org/10.1242/jcs. 158550

41. Merkulova M, Paunescu TG, Azroyan A, Marshansky V, Breton S, Brown D (2015) Mapping the H(+) (V)-ATPase interactome: identification of proteins involved in trafficking, folding, assembly and phosphorylation. Sci Rep 5:14827. https://doi.org/10.1038/ srep14827

42. Moestrup SK, Nielsen S, Andreasen P, Jorgensen KE, Nykjaer A, Roigaard H, Gliemann J, Christensen EI (1993) Epithelial glycoprotein-330 mediates endocytosis of plasminogen activatorplasminogen activator inhibitor type-1 complexes. J Biol Chem 268:16564-16570

43. Mrschtik M, Ryan KM (2015) Lysosomal proteins in cell death and autophagy. FEBS J 282:1858-1870. https://doi.org/10.1111/ febs. 13253

44. Myakala K, Motta S, Murer H, Wagner CA, Koesters R, Biber J, Hernando N (2014) Renal-specific and inducible depletion of $\mathrm{NaPi}-\mathrm{IIc} / \mathrm{Slc} 34 \mathrm{a} 3$, the cotransporter mutated in HHRH, does not affect phosphate or calcium homeostasis in mice. Am J Physiol Renal Physiol 306:F833-F843. https://doi.org/10.1152/ajprenal. 00133.2013

45. Nguyen G, Delarue F, Burckle C, Bouzhir L, Giller T, Sraer JD (2002) Pivotal role of the renin/prorenin receptor in angiotensin II production and cellular responses to renin. J Clin Invest 109:1417-1427. https://doi.org/10.1172/JCI14276

46. Nguyen G, Muller DN (2010) The biology of the (pro)renin receptor. J Am Soc Nephrol 21:18-23. https://doi.org/10.1681/ASN. 2009030300
47. Nielsen R, Christensen EI, Birn H (2016) Megalin and cubilin in proximal tubule protein reabsorption: from experimental models to human disease. Kidney Int 89:58-67. https://doi.org/10.1016/j. kint.2015.11.007

48. Norgett EE, Golder ZJ, Lorente-Canovas B, Ingham N, Steel KP, Karet Frankl FE (2012) Atp6v0a4 knockout mouse is a model of distal renal tubular acidosis with hearing loss, with additional extrarenal phenotype. Proc Natl Acad Sci U S A 109:13775-13780. https://doi.org/10.1073/pnas.12042 57109

49. Oshima Y, Kinouchi K, Ichihara A, Sakoda M, Kurauchi-Mito A, Bokuda K, Narita T, Kurosawa H, Sun-Wada GH, Wada Y, Yamada T, Takemoto M, Saleem MA, Quaggin SE, Itoh H (2011) Prorenin receptor is essential for normal podocyte structure and function. J Am Soc Nephrol 22:2203-2212. https://doi.org/10. 1681/ASN.2011020202

50. Pena-Llopis S, Vega-Rubin-de-Celis S, Schwartz JC, Wolff NC, Tran TA, Zou L, Xie XJ, Corey DR, Brugarolas J (2011) Regulation of TFEB and V-ATPases by mTORC1. EMBO J 30:32423258. https://doi.org/10.1038/emboj.2011.257

51. Peng SB, Li X, Crider BP, Zhou Z, Andersen P, Tsai SJ, Xie XS, Stone DK (1999) Identification and reconstitution of an isoform of the 116-kDa subunit of the vacuolar proton translocating ATPase. J Biol Chem 274:2549-2555

52. Peters J (2017) The (pro)renin receptor and its interaction partners. Pflugers Arch 469:1245-1256. https://doi.org/10.1007/ s00424-017-2005-z

53. Piwon N, Gunther W, Schwake M, Bosl MR, Jentsch TJ (2000) ClC-5 $\mathrm{Cl}^{-}$-channel disruption impairs endocytosis in a mouse model for Dent's disease. Nature 408:369-373

54. Popova E, Bader M, Krivokharchenko A (2005) Strain differences in superovulatory response, embryo development and efficiency of transgenic rat production. Transgenic Res 14:729-738. https:// doi.org/10.1007/s11248-005-7218-9

55. Ramachandran N, Munteanu I, Wang P, Ruggieri A, Rilstone JJ, Israelian N, Naranian T, Paroutis P, Guo R, Ren ZP, Nishino I, Chabrol B, Pellissier JF, Minetti C, Udd B, Fardeau M, Tailor CS, Mahuran DJ, Kissel JT, Kalimo H, Levy N, Manolson MF, Ackerley CA, Minassian BA (2013) VMA21 deficiency prevents vacuolar ATPase assembly and causes autophagic vacuolar myopathy. Acta Neuropathol 125:439-457. https://doi.org/10.1007/ s00401-012-1073-6

56. Ramkumar N, Stuart D, Calquin M, Quadri S, Wang S, Van Hoek AN, Siragy HM, Ichihara A, Kohan DE (2015) Nephron-specific deletion of the prorenin receptor causes a urine concentration defect. Am J Physiol Renal Physiol 309:F48-F56. https://doi.org/ 10.1152/ajprenal.00126.2015

57. Ramkumar N, Stuart D, Mironova E, Bugay V, Wang S, Abraham N, Ichihara A, Stockand JD, Kohan DE (2016) Renal tubular epithelial cell prorenin receptor regulates blood pressure and sodium transport. Am J Physiol Renal Physiol:ajprenal 0008802016. https://doi.org/10.1152/ajprenal.00088.2016

58. Ramser J, Abidi FE, Burckle CA, Lenski C, Toriello H, Wen G, Lubs HA, Engert S, Stevenson RE, Meindl A, Schwartz CE, Nguyen G (2005) A unique exonic splice enhancer mutation in a family with X-linked mental retardation and epilepsy points to a novel role of the renin receptor. Hum Mol Genet 14:1019-1027. https://doi.org/10.1093/hmg/ddi094

59. Riediger F, Quack I, Qadri F, Hartleben B, Park JK, Potthoff SA, Sohn D, Sihn G, Rousselle A, Fokuhl V, Maschke U, Purfurst B, Schneider W, Rump LC, Luft FC, Dechend R, Bader M, Huber TB, Nguyen G, Muller DN (2011) Prorenin receptor is essential for podocyte autophagy and survival. J Am Soc Nephrol 22:2193-2202. https://doi.org/10.1681/ASN.2011020200

60. Rong R, Ito O, Mori N, Muroya Y, Tamura Y, Mori T, Ito S, Takahashi K, Totsune K, Kohzuki M (2015) Expression of (pro) 
renin receptor and its upregulation by high salt intake in the rat nephron. Peptides 63:156-162. https://doi.org/10.1016/j.pepti des.2014.12.007

61. Rousselle A, Sihn G, Rotteveel M, Bader M (2014) (Pro)renin receptor and V-ATPase: from Drosophila to humans. Clin Sci (Lond) 126:529-536. https://doi.org/10.1042/CS20130307

62. Rujano MA, Cannata Serio M, Panasyuk G, Peanne R, Reunert J, Rymen D, Hauser V, Park JH, Freisinger P, Souche E, Guida MC, Maier EM, Wada Y, Jager S, Krogan NJ, Kretz O, Nobre S, Garcia P, Quelhas D, Bird TD, Raskind WH, Schwake M, Duvet S, Foulquier F, Matthijs G, Marquardt T, Simons M (2017) Mutations in the X-linked ATP6AP2 cause a glycosylation disorder with autophagic defects. J Exp Med 214:3707-3729. https://doi.org/10.1084/jem.20170453

63. Schefe JH, Menk M, Reinemund J, Effertz K, Hobbs RM, Pandolfi PP, Ruiz P, Unger T, Funke-Kaiser H (2006) A novel signal transduction cascade involving direct physical interaction of the renin/prorenin receptor with the transcription factor promyelocytic zinc finger protein. Circ Res 99:1355-1366. https://doi. org/10.1161/01.RES.0000251700.00994.0d

64. Schulz N, Dave MH, Stehberger PA, Chau T, Wagner CA (2007) Differential localization of vacuolar H+-ATPases containing a1, a2, a3, or a4 (ATP6V0A1-4) subunit isoforms along the nephron. Cell Physiol Biochem 20:109-120

65. Schwake M, Schroder B, Saftig P (2013) Lysosomal membrane proteins and their central role in physiology. Traffic 14:739-748. https://doi.org/10.1111/tra.12056

66. Seva Pessoa B, van der Lubbe N, Verdonk K, Roks AJ, Hoorn EJ, Danser AH (2013) Key developments in renin-angiotensin-aldosterone system inhibition. Nat Rev Nephrol 9:26-36. https://doi.org/10.1038/nrneph.2012.249

67. Sihn G, Rousselle A, Vilianovitch L, Burckle C, Bader M (2010) Physiology of the (pro)renin receptor: Wnt of change? Kidney Int 78:246-256. https://doi.org/10.1038/ki.2010.151

68. Sun-Wada GH, Wada Y (2013) Vacuolar-type proton pump ATPases: acidification and pathological relationships. Histol Histopathol 28:805-815

69. Traykova-Brauch M, Schonig K, Greiner O, Miloud T, Jauch A, Bode M, Felsher DW, Glick AB, Kwiatkowski DJ, Bujard
H, Horst J, von Knebel DM, Niggli FK, Kriz W, Grone HJ, Koesters R (2008) An efficient and versatile system for acute and chronic modulation of renal tubular function in transgenic mice. Nat Med 14:979-984. https://doi.org/10.1038/nm.1865

70. Trepiccione F, Gerber SD, Grahammer F, Lopez-Cayuqueo KI, Baudrie V, Paunescu TG, Capen DE, Picard N, Alexander RT, Huber TB, Chambrey R, Brown D, Houillier P, Eladari D, Simons M (2016) Renal Atp6ap2/(Pro)renin receptor is required for normal vacuolar $\mathrm{H}+$-ATPase function but Not for the Renin-Angiotensin System. J Am Soc Nephrol. https://doi. org/10.1681/ASN.2015080915

71. Wagner CA, Finberg KE, Breton S, Marshansky V, Brown D, Geibel JP (2004) Renal vacuolar $\mathrm{H}^{+}$-ATPase. Physiol Rev 84:1263-1314

72. Wagner CA, Lukewille U, Valles P, Breton S, Brown D, Giebisch GH, Geibel JP (2003) A rapid enzymatic method for the isolation of defined kidney tubule fragments from mouse. Pflugers Arch 446:623-632

73. Wang SS, Devuyst O, Courtoy PJ, Wang XT, Wang H, Wang Y, Thakker RV, Guggino S, Guggino WB (2000) Mice lacking renal chloride channel, CLC-5, are a model for Dent's disease, a nephrolithiasis disorder associated with defective receptor-mediated endocytosis. Hum Mol Genet 9:2937-2945

74. Xu H, Ren D (2015) Lysosomal physiology. Annu Rev Physiol 77:57-80. https://doi.org/10.1146/annurev-physi ol-021014-071649

75. Zoncu R, Bar-Peled L, Efeyan A, Wang S, Sancak Y, Sabatini DM (2011) mTORC1 senses lysosomal amino acids through an inside-out mechanism that requires the vacuolar $\mathrm{H}(+)$-ATPase. Science 334:678-683. https://doi.org/10.1126/science.1207056

Publisher's Note Springer Nature remains neutral with regard to jurisdictional claims in published maps and institutional affiliations. 